\title{
Sea-level control on the connection between shelf-edge deltas and the Bourcart canyon head (western Mediterranean) during the last glacial/interglacial cycle
}

\author{
Mauffrey M.A. ${ }^{1,}{ }^{*}$, Berné Serge ${ }^{1}$, Jouet Gwenael ${ }^{2}$, Giresse P. ${ }^{1}$, Gaudin M. ${ }^{3}$ \\ ${ }^{1}$ Université de Perpignan, Laboratoire CEFREM, UMR-CNRS 5110, 52 Av. P. Alduy, 66860 Perpignan, \\ France \\ 2 Ifremer, Géosciences Marines, BP 70, 29280 Plouzané, France \\ ${ }^{3}$ TullowOil, Oslo, Norway \\ *Corresponding author : M.A. Mauffrey, email address : marie-aline.mauffrey@univ-perp.fr
}

\begin{abstract}
:
A dense grid of high- and very high resolution seismic data, together with piston cores and borehole data providing time constraints, enables us to reconstruct the history of the Bourcart canyon head in the western Mediterranean Sea during the last glacial/interglacial cycle. The canyon fill is composed of confined channel-levee systems fed by a series of successively active shelf fluvial systems, originating from the west and north. Most of the preserved infill corresponds to the interval between Marine Isotope Stage (MIS) 3 and the early deglacial (19 cal ka BP). Its deposition was strongly controlled by a relative sea level that impacted the direct fluvial/canyon connection. During a period of around $100 \mathrm{kyr}$ between MIS 6 and MIS 2, the canyon "prograded" by about $3 \mathrm{~km}$. More precisely, several parasequences can be identified within the canyon fill. They correspond to forced-regressed parasequences (linked to punctuated sea-level falls) topped by a progradational-aggradational parasequence (linked to a hypothetical 19-ka meltwater pulse (MWP)). The bounding surfaces between forced-regressed parasequences are condensed intervals formed during intervals of relative sediment starvation due to flooding episodes. The meandering pattern of the axial incision visible within the canyon head, which can be traced landward up to the Agly paleo-river, is interpreted as the result of hyperpycnal flows initiated in the river mouth in a context of increased rainfall and mountain glacier flushing during the early deglacial.
\end{abstract}




\section{Graphical abstract :}

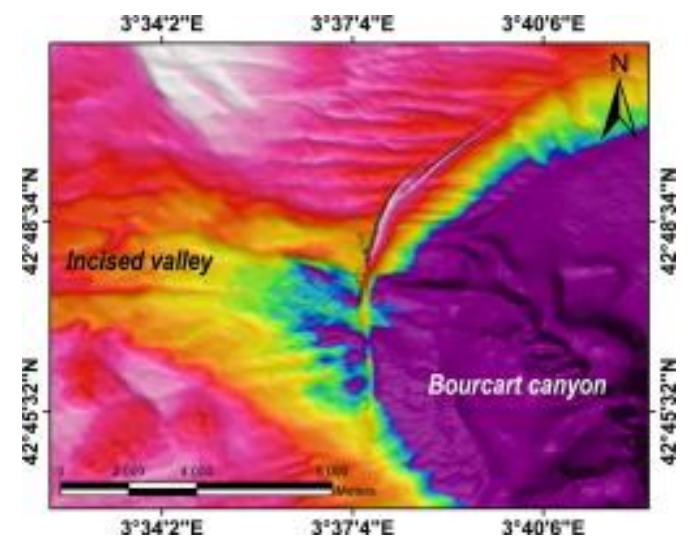

Keywords: Submarine canyon, Confined channel-levee systems, Mass transport deposits, Bond cycles, Sea level

\section{Highlights}

First detailed chronology of canyon head infill, which took place between 38 and 19 ka BP during the last glacial cycle, Fluvial connection (in relation with sea-level changes) is the key controlling parameter. - The seismic stratigraphic motif consists in confined channel-levee systems with chaotic infill, topped by fluvial facies. Large MTDs are related to Bond cycles.

\section{1- Introduction}

There are relatively few studies focusing on the relationship between canyon infill, fluvial delivery to canyon heads and relative sea-level changes. Most of the textbooks on sequence stratigraphy (e.g. (Posamentier et al., 1988); (Catuneanu, 2006)) include canyons in slope and deep-sea facies, which are viewed as part of the lowstand (or falling stage) and transgressive systems tracts (Rasmussen, 1994, 1997). The Quaternary, and especially the last Glacial/Interglacial cycle, offers the possibility to investigate precise processes that control fluvial/canyon connections, because most of the world's fluvial systems reached the shelf edge during the Last Glacial Maximum (LGM, between ca. 26.5 and $19 \mathrm{ka} \mathrm{BP}$ ).

Several mechanisms have been proposed to explain the origin of canyons, which are common features observed along modern (Quaternary) continental margins, as well as features that are buried in the stratigraphic record. Two main processes (not necessarily mutually exclusive) are generally proposed and have been the object of reviews and discussions (i.e. Mountain et al. (1996); Pratson and Coakley (1996); Pratson et al. (1994)). 
1- Initiation of turbidity currents (and/or mass failure) at the mouth of a fluvial system situated in the vicinity of the shelf edge. Daly (1936) was the first to introduce the idea of turbidity currents as the major factor in the formation and erosion of submarine canyons in relation to sea-level variations. This mechanism of canyon formation implies overloading through sediment accumulation at the river mouth (Pratson et al., 1994) triggering mass failure and/ or the initiation of hyperpycnal flows within the river, evolving into a turbidity current along the slope (Mulder et al., 2003; Normark and Piper, 1991). In the Gulf of Lions, Baztan et al. (2005) suggested that the connection of fluvial systems at some canyon heads during the Last Glacial Maximum resulted in the formation of narrow (300 m wide) axial incisions, about $100 \mathrm{~m}$ deep, cutting across the thalweg of the main canyons. It was proposed that this process also accounts for the broadening of the main canyon through the lateral collapse of the canyon rims, due to retrogressive slides triggered along the axial incision (Sultan et al., 2007). Instead of direct sediment delivery from rivers, littoral drift can be the main source feeding canyon heads when the continental shelf is narrow or absent (Shepard, 1972; Shepard and Dill, 1977). This is the case of Mandji Island, in the vicinity of the Ogooue River mouth on the Gabonese Margin (Cap Lopez Canyon, Biscara et al., (2011)), to the North of Fraser Island on the east coast of Australia (Boyd et al., 2008), or for the La Jolla canyon on the Californian margin (Covault et al., 2007). In these cases, however, sediment transfer to the deep sea is channelized within several gullies, rather than through a distinct axial incision meandering within a broad canyon.

2- Mass failure on the slope evolving through retrogressive erosion that may eventually "capture" fluvial systems. This scenario was based on the observation by Twichell and Roberts (1982) that some canyons cut across the shelf edge, whereas others are confined to the continental slope, the former (and older) resulting from 
headward erosion of the second (younger) type. This idea was also developed by Farre et al. (1983) who proposed a scenario with an initial phase dominated by slope failure, followed by the development of coarse-grained turbiditic flows fed by offshore sands after the canyon head reaches the shelf edge. This "bottom-up" scenario has been proposed to explain the origin of the Yoakum/Lavaca canyon system (Gulf of Mexico) (Galloway et al., 1991), the Andǿya canyon (Norwegian Sea) (Laberg et al., 2007) or the Bari canyon (Adriatic sea) (Ridente et al., 2007), which are not related to any river. This scenario was also proposed to explain the formation of canyons where buried paleovalleys exist on the shelf such as of the Otero River (Lo lacono et al., 2013). Similarly, the formation of some canyons of the Argentine Continental Margin is explained by headward retrogressive erosion, increased by strong contour currents (Lastras et al., 2011). Headward erosion and lateral migration controlled by contour currents is also proposed as the mechanism at the origin of buried late Miocene canyons in the South China Sea (He et al., 2013).

These two scenarios were reconciled by Pratson and Coakley (1996) who showed, through numerical modeling, that retrogressive failure along the mid-slope can be triggered by downslope currents initiated at the shelf edge (possibly at the river mouth) and flowing along rills. In addition to these two general scenarios of canyon formation, fluid escape has been proposed as an important mechanism in the initiation and/or evolution of some canyons, such as the Benito canyon off the Equatorial Guinean coasts (Jobe et al., 2011) or along the eastern margin of Japan, where pockmarks formed by release of hydrostatic pressure during sea-level falls might be at the origin of the canyons (Nakajima et al., 2014), 
In any event, as already mentioned by Shepard (1981), it is likely that most canyons result from a combination of various processes operating over long periods of time, interrupted by intervals of non-deposition or condensation. For instance, the history of the Tugela Canyon on the east coast of South Africa is related to several phases of hinterland uplift, at the origin of incisions, followed by pelagic infill and reworking by oceanic currents (Wiles et al., 2013). In the Bay of Biscay, the Capbreton canyon that cuts across the broad Aquitaine shelf displays a very meandering pattern and a distinct axial incision that is interpreted as being inherited from the period of connection of the canyon head with the Adour River (Gaudin et al., 2006). However, during the last decade, the canyon experienced distinct morphological and sedimentological evolution due to massive transfer of sand eroded from the coastline during major storms (Mazières et al., 2013).

2- In this paper, we focus on the head of the Bourcart Canyon in the Gulf of Lions (western Mediterranean). A large number of seismic profiles at different resolutions, as well as one long piston core and two boreholes (100 and $300 \mathrm{~m}$ deep), allow us to reconstruct the architecture and the history of the canyon head during the last Glacial/Interglacial cycle in relation with the relative sealevel changes and the question of connection/disconnection of the fluvial system(s). Geological framework

The Bourcart canyon is located at the western end of the Gulf of Lions (Fig. 1). The canyon starts at about 110 to $120 \mathrm{~m}$ water depth, $60 \mathrm{~km}$ from the present coastline. The Gulf of Lions is a passive and prograding margin influenced by a significant subsidence rate (about $250 \mathrm{~m} /$ Myr at the shelf edge) (Rabineau et al., 2014) and high sediment supply, mainly from the Rhone River. As a result, depositional sequences linked to Milankovitch and sub-orbital Quaternary sea-level changes are well preserved at the shelf edge and along the upper 
continental slope (i.e.(Bassetti et al., 2008; Jouet et al., 2006; Rabineau et al., 2005; Tesson et al., 2000). These units mainly consist in forced-regressive sequences, which thicken seaward and pinch out landward at a depth of $100 \mathrm{~m}$. The continental slope is deeply incised by numerous canyons, some with a depth in excess of $1000 \mathrm{~m}$ (Berné et al., 1999). Among these, the Petit Rhone canyon to the east was, at least during the last glacial cycle, the main conduit of sediment between the Rhone watershed and the Rhone Deep Sea Fan, which drains all the canyons from the central and western Gulf of Lions (Fig. 1).

Because of overall subsidence and high sediment supply, fossil canyons have been rapidly buried. Except for the Rhone canyon, most canyons were initiated around the Middle-Late Pliocene and reached full development (similar in size to modern canyons) around the Pliocene-Quaternary transition (Lofi et al., 2003). This canyon evolution might be related to the amplification of Glacial-Interglacial cycles at the end of the Pliocene (Lisiecki and Raymo, 2005) and related sea-level changes.

\section{3- Data set and Methodology}

\section{1- Bathymetric data}

The overall study area is covered by two multi-beam data sets acquired by R/V "Le Suroît" during several cruises using Simrad EM300 and EM1000 systems. For the purpose of this study, a Digital Terrain Model (DTM) with a grid spacing of $50 \mathrm{~m}$ was produced.

\section{2- Seismic data}

$1500 \mathrm{~km}$ of high- and very high-resolution seismic profiles were acquired over the Bourcart canyon head (about $50 \mathrm{~km}^{2}$; Fig. 2). This data set includes 24-fold multi-channel and single channel seismic profiles. Multi-channel seismic data was acquired during the "Marion" cruise aboard R/V "Le Suroît" using two Sodera ${ }^{T M}$ mini-Gl gun sources and a 24-channel 
(6.25 m, 8 hydrophones per trace) streamer. For higher resolution, we used SIG ${ }^{\mathrm{TM}}$ sparker equipment (700 J power emission, $1.5 \mathrm{~s}$ shooting rate) and a hull-mounted, IXSEA ${ }^{\mathrm{TM}}$ chirp sub-bottom profiler (20 to $50 \mathrm{~ms}$ pulse length, $2000-5200 \mathrm{~Hz}$ bandwidth) during several cruises of R/V "Le Suroît". These different systems give vertical resolutions in the order of $>3 \mathrm{~m}, 1 \mathrm{~m}$ and $<1 \mathrm{~m}$, respectively. Seismic and borehole data were transferred to an interpretation station (SMT Kingdom Suite ${ }^{\mathrm{TM}}$ ). Seismic interpretation was based on the principle of seismic stratigraphy (Mitchum et al., 1977). Major seismic surfaces were plotted in a manual or semi-automated mode over the entire study area. For the correlation of these surfaces with borehole information, we used seismic velocity determined at sites PRGL1 and PRGL2 by the Promess project (see below).

\section{3- Chrono-stratigraphic constraints}

We used all the age controls from both PRGL1 and PRGL2 boreholes and from Images 5 cores MD99-2349 and MD99-2348. P-wave sonic velocities were determined along cores by direct sonic velocity measurements using a Multi-Sensor Core Logger (MSCL, Geotek $\left.^{T M}\right)$, together with interval velocity analysis performed on multi-channel seismic data at the position of borehole PRGL1 (Dennielou, 2007). Sonic velocity analysis allowed us to tie seismic surfaces to core and borehole data and thus to infer ages for each surface thanks to robust chrono-stratigraphic constraints established for PRGL1 and MD99-2348 (Frigola et al., 2012; Jouet et al., 2006; Sierro et al., 2009). Analysis and dating on PRGL2 (Bassetti et al., 2008) and MD99-2349 (Jouet et al., 2006) were used as points of reference or checkpoints while propagating seismic surfaces from PRGL1 and/or MD99-2348 to the shelf.

In a first approach, seismic surfaces at the position of the borehole are considered as timelines and can be propagated around and within the canyon head. We will discuss the 
precise chrono-stratigraphic significance of each type of seismic bounding surface in the following section.

In order to compare already published results from the Promess boreholes and new ${ }^{14} \mathrm{C}$ dates from beachrock samples, all ages were re-calibrated using CALIB 7.0.2 with Marine13 calibration (Stuiver and Reimer, 1993). It was corrected for a 400-year air-sea reservoir age effect and performed at the Poznan Radiocarbon Laboratory. For the chronology of major climatic events, we used the lettered substages of Railsback et al. (2015). The terminology for sub-orbital climatic events is based on the Greenland chronology (North Greenland Ice Core Project members, 2004), synchronized with the Mediterranean record by Sierro et al. (2009).

\section{4- Results}

\section{1- Shelf and slope morphology around the Bourcart canyon}

The morphology of our study area has already been studied by Baztan et al. (2005) and Bassetti et al. (2006). The resolution of new swath bathymetric data sheds new light on several morphological features and the connection between canyons and fluvial systems. The Bourcart canyon head (the upper part of the canyon, comprised between 120 and $500 \mathrm{~m}$ water depth) displays a deep (50-400 m) and broad (2-5 km) major incision indenting the shelf along a distance of about $10 \mathrm{~km}$ (Figs. $3 \mathrm{~A}$ and $\mathrm{B}$ ). Both rims of the canyon are indented by several slump scars. The bottom of the canyon head presents an axial incision in the sense of Baztan et al. (2005), $50 \mathrm{~m}$ deep and $400-800 \mathrm{~m}$ wide (Figs. 3A and B). Between about $230 \mathrm{~m}$ down to about $370 \mathrm{~m}$ water depth, the axial incision is markedly meandering with a sinuosity index (ratio of the curvilinear length to the straight length) of approximately 2. Beyond $-370 \mathrm{~m}$, the incision becomes almost straight, in relation to an abrupt increase of the overall slope of the canyon as shown in Fig. 4. 
In the Gulf of Lions, the shelf-to-slope transition (the "shelf break") is marked by an increase of $0.1^{\circ}$ to $1.5^{\circ}$ of the overall gradient (Baztan et al., 2005). As it varies strongly between canyon heads and interfluves, we chose a value of $0.5^{\circ}$ as the boundary between the two domains. In most of the canyons in the Gulf of Lions, including the Bourcart canyon, the shelf break is situated at a present water depth of about $120 \mathrm{~m}$ around the canyon head, in contrast with a depth of about $-160 \mathrm{~m}$ along the Bourcart/Herault interfluve, where the smooth morphology is affected by several pockmarks (Fig. 3A). Further east, the four branches of the Herault canyon (labeled H1 to H4) display contrasted morphologies, with $\mathrm{H} 2$ and $\mathrm{H} 3$ incised by meandering axial incisions merging at about $500 \mathrm{~m}$ water depth (Figs. $3 \mathrm{~A}$ and $\mathrm{C}$ ). In contrast, $\mathrm{H} 1$ and $\mathrm{H} 4$ do not display any axial incision, the upper part of $\mathrm{H} 1$ being largely infilled by sediment down to a depth of about $340 \mathrm{~m}$, where a major slump scar is visible (Fig. 3A).

On the shelf, several distinct features are noticeable on swath bathymetric maps, also of interest for understanding the history of canyons and their connections with fluvial systems.

- Beach rocks- The most pronounced relief corresponds to the $7 \mathrm{~km}$ long "Pierres de Sete", parallel to bathymetric contour lines (1 in Figs. 3A and B, Fig. 4). It culminates at $90 \mathrm{~m}$, about $21 \mathrm{~m}$ above the surrounding seafloor. This relief corresponds to beachrocks formed by the cementation of littoral sands during the last glacial period (Jouet et al., 2006). The precise nature and age of this feature will be discussed later.

- Seaward limit of "offshore sands"- All along the outer shelf in the Gulf of Lions, and in particular in the Bourcart-Herault area, a distinct notch, parallel to contour lines, can be traced at a water depth around $120 \mathrm{~m}$ (2 in Fig. 3A). This step corresponds to the boundary between the upper (sandy) and lower (clayey) shoreface that formed in response to the last forced regression, between Marine Isotope Stage (MIS) 3 and MIS 2 (Bassetti et al., 2008). Interestingly, in our area this step corresponds to the 
pinch out of the axial incisions at the Bourcart canyon head. Upward of this boundary and up to a water depth of about 80 to $90 \mathrm{~m}$, a broad domain of relict sands ("offshore sands" in the sense of Emery (1968)), covers the outer continental shelf (3 in Figs. 3A and $B$ ).

- Sand ridges- the offshore sands are reworked into transgressive E-W-oriented sand ridges ( 3 in Figs. $3 \mathrm{~A}$ and $\mathrm{B}$ ), up to $9 \mathrm{~m}$ high and several $\mathrm{km}$ in length (Bassetti et al., 2006). According to these authors, the ridges formed around 12,000 cal years $\mathrm{BP}$, at a time when water depth was $<50 \mathrm{~m}$.

- "Shelf Valley Complexes" (SVC)- This concept was proposed by (Swift, 1973) and further developed by Swift et al. (1991), to describe the landward shift of depo-center estuary mouths in response to relative sea-level rise. The resulting morphology of this process consists of levee-like shoals (topographic highs), paired with a shelf valley (topographic low; Fig. 3C). This concept is important in the Gulf of Lions because it allows us to recognize the retreat path of river mouths (from bathymetric maps) as elongated topographic highs and/or lows, roughly perpendicular to the contour lines. SVC1 and SVC2 (Fig. 3C) have been mapped landward, where they form distributaries of the Rhone transgressive fluvial system (Berné et al., 2007; Gensous and Tesson, 2003).

- "Incised valleys"- Despite the fact that valleys are incised by definition (Blum and Törnqvist, (2000), the term of incised valley is commonly used to describe elongated erosional features formed by fluvial erosion. In our study area, a major incised valley, oriented WNW-ESE, $6 \mathrm{~km}$ wide and up to $18 \mathrm{~m}$ deep, is visible to the west of the Bourcart canyon ("western incised valley" in Fig. 3B). Seismic profiles show that it carves across forced-regressed deposits of MIS 3-MIS 2 (Fig. 5). This incised valley is 
tentatively linked to the Tet-Agly paleo-valley mapped by Tesson et al. $(2011 ; 2015)$

on the inner and middle shelf (down to a present water depth of about $90 \mathrm{~m}$ ).

In summary, the study area provides some evidence of the presence of streams reaching the shelf edge. The seaward terminations of these features (either shelf valley complexes or incised valleys) are in continuity, at the shelf edge, with meandering axial incisions within the Bourcart, Herault 1 and Herault 2 canyons (Fig. 3). In contrast, canyons without axial incisions (Herault 3 and 4 ) do not exhibit any remnant of a fluvial system from MIS 3-MIS 2 at the shelf edge (Fig. 3).This observation strongly suggests a genetic link between meandering axial incisions and fluvial connections.

\section{2- Interpretation of seismic data and correlation with core/borehole data}

We used here the principles and terminology of seismic stratigraphy (Mitchum et al., 1977) to describe seismic surfaces and facies. Regarding gravity deposits within the Bourcart canyon head, we used the terms defined and ground-truthed during ODP leg 155 (Normark et al., 1997).

\subsection{1- Seismic surfaces and their chronostratigraphic constraints}

A hierarchy of seismic bounding surfaces is observed in the study area for the interval corresponding to the last ca. $120 \mathrm{kyr}$, with major seismic bounding surfaces linked to $100 \mathrm{kyr}$ glacial-interglacial cycles and second-order surfaces linked to sub-orbital climate/sea-level changes. These surfaces have been dated at the position of cores and boreholes (Bassetti et al., 2008; Bassetti et al., 2006; Jouet et al., 2006; Sierro et al., 2009). They may represent a relatively important time span in the case of condensed or erosive intervals, so it is more relevant for this study to assign them a significance in terms of climatic/sea-level change events. Their main characteristics, age at the position of 
cores/boreholes, and relations with climate/sea-level changes are summarized below and in Figures 6, 7 and Table 1.

\section{Major bounding surfaces linked to $100 \mathrm{kyr}$ glacial/interglacial cycles}

Major bounding surfaces are sequence boundaries on the shelf and maximum flooding surfaces on the continental slope.

-The sequence boundaries (or maximum regressive surfaces in the sense of Catuneanu et al., (2009)), labeled with an "s", formed during the last (MIS 2) and penultimate (MIS 6.a) Glacial Maxima (D70s and D60s, respectively) (Table 1, Figs. 6, 7 and 8). These surfaces are very pronounced shelfal erosion surfaces, with topset terminations. Seaward, they become progressively conformable near or beyond the shelf edge, where they lose any distinct seismic character. The correlative conformity of the LGM sequence boundary (D70s) is dated at about 20 cal ka BP near the shelf edge (Jouet et al., 2006). D60s is the sequence boundary of MIS 6.a. Its correlative conformity is situated at $73 \mathrm{~m}$ below the seafloor at the position of borehole PRGL1 (Sierro et al., 2009), immediately below the maximum flooding surface of MIS 5.e (see below).

-The Maximum Flooding Surfaces (MFS), labeled with an "m" (respectively D70m, merged with the seafloor in the study area, and D60m) are the most distinguishable seismic surfaces on the continental slope, where they display distinct high amplitude, continuous reflections with toplap and onlap terminations (Table 1, Figs. 6, 7 and 8). These outer shelf/upper slope surfaces are called MFS because they are synchronous with the downlap surfaces formed on the inner shelf at the time when the coastline reached its maximum landward position (Posamentier and Allen, 1999), i.e. during MIS 1 and MIS 5.e. They are condensed intervals because deposition shifted landward during warm interglacials, with coarser grain-size due to winnowing (Sierro et al., 2009). 
Note that, at the seismic resolution scale, sequence boundaries and maximum flooding surfaces merge on the outer shelf, except at the position of incised valley fills or transgressive sand ridges.

\section{Seismic surfaces linked to sub-orbital climate and sea-level changes}

In addition to $100 \mathrm{kyr}$ cycles, the sea-level history during MIS 3-MIS 2 was strongly marked by rapid warming and cooling events, named Dansgaard-Oescheger events. These millennial-scale climatic events are bundled into so-called Bond cycles ended by Heinrich events in the North Atlantic (Bond et al., 1993). Outside the Atlantic realm, these cold events are called Heinrich Stadials (HS). The sea-level changes linked to these rapid climate changes are in the order of 15-35 m (i.e. (Arz et al., 2007; Shackleton, 2000; Siddall et al., 2008)), with slow sea-level falls (ended by Heinrich events) followed by rapid sealevel rises (ibid.). These falls and rises are at the origin of distinct seismic surfaces, correlated with core and borehole data, and are interpreted as regressive erosion surfaces (labeled with an $r$ ) and flooding surfaces (labeled with an $f$ ), respectively (Figs. 7 and 8). Of particular interest for this study are surfaces that formed between ca. 40 and 18 ka BP, which are well preserved in and around the canyon head, and which were propagated over the entire study area thanks to the dense seismic coverage.

Flooding surfaces. At the position of hole PRGL1, D63f, D64f and D65f are high-amplitude reflections with distinct toplap and onlap terminations (Figs. 7, 8 and Table 1). On the cores they correspond to relatively coarse-grained, condensed intervals about 5 to $30 \mathrm{~cm}$ thick. These are rich in micro-fauna typical of warm to temperate intervals and have a sedimentation rate in the order of $0.1 \mathrm{~m} / \mathrm{kyr}$ (compared to $2.5 \mathrm{~m} / \mathrm{kyr}$ for cold intervals (Sierro et al., 2009). They are linked to the longest warm Greenland Interstadials 8, 4 and 2, 
respectively (Sierro et al., 2009)). These surfaces are mapable over the upper slope and in the canyon head. Updip, they merge with the underlying regressive erosion surfaces.

Regressive erosion surfaces. The surfaces labeled D63r, D64r and D65r are better observed on the outer shelf and upper slope (including the upper canyon head) where they are distinct erosion surfaces (Figs. 6, 7, 8 and Table 1). They correspond to the most pronounced sea-level falls during the coldest stadials, which were terminated by Heinrich Stadials 4, 3 and 2, respectively (Hemming, 2004).

Finally, D67 was introduced as a timeline with no distinct expression along the slope and in the canyon head, but with high amplitude on the shelf, where it was used to pre-date some buried channels (Figs. 6, 7, 8 and Table 1).

The position of various seismic surfaces with respect to a composite sea-level curve is summarized in figure 8 . Note that the age of each surface can vary slightly depending on its position because erosion/condensation does not occur simultaneously along the same surface. Between bounding surfaces, seismic units (U1 to U3) have been defined, as well as sub-units within $\mathrm{U} 2$ (U2a to U2c; Table 1).

Age of the sea-floor. By definition, seafloor sediment corresponds to the present-day conditions of sedimentation. However, several studies have shown that a condensed interval covers the outer shelf and the continental slope (including the Bourcart canyon head) in our study area (i.e. (Bassetti et al., 2006; Jouet et al., 2006)). This interval, from a few centimeters to about $1 \mathrm{~m}$ thick, consists of sand resulting from the winnowing of the seafloor by dense water cascades (Gaudin et al., 2006), wind-driven currents generated by SE storms (Bassetti et al., 2006; Jouet et al., 2006) and the Liguro-Provencal geostrophic current (Sierro et al., 2009). This condensed interval overlies consolidated silts and clays dated between 15 and $20 \mathrm{ka} \mathrm{BP}$ by the same authors. The situation is similar on the outer 
shelf, with the exception of episodically mobile sand dunes that cannibalize the lowstand shoreface sands (Bassetti et al., 2006). In summary, most of the outer shelf and continental slope represent, at the seismic resolution scale, a condensed interval that initiated around 17 cal ka BP, when depo-centers shifted landward during the global deglacial sea-level rise.

\subsection{2- Time constraints from beach rocks}

In addition to direct time constraints obtained from borehole and core data, we used the age of formation of the "Pierres de Sete" beachrocks to postdate some events. The samples dredged from the top of the Pierres de Sete (90-91 m water depth) are composed of lithified coarse sands. Quartz grains are dominant but some dark gray siltstone or marl-detrital grains (1 $\mathrm{mm}$ diameter) are common or even dominant and constitute coarser $(1-5 \mathrm{~cm}$ thick) intervals. This siltstone characterizes the sediment from the Agly River that flows from the NE rim of the Pyrenees Mountains (Fig. 1; (Berger et al., 1993)).

The cement consists of sparry calcite, with $10 \mu \mathrm{m}$ long crystals, arranged in isopachous and palisadic rims around the grains. Diffractometric analyses indicate that these grains are mainly magnesian calcite ranging from 14 to 26 mole $\% \mathrm{MgCO}_{3}$, similar to the composition of other Mediterranean beachrocks (Alexandersson, 1972). This suggests a one-stage rapid cementation within the groundwater table, in the vicinity of the sea.

The AMS-dating of cements of the lower and upper part of a $10 \mathrm{~cm}$ sample give respectively the ages of $18,882( \pm 92)$ and $17,896( \pm 114)$ a cal BP (Table 2$)$. The beach rocks are stratigraphically above the most recent fluvial/canyon incisions (Fig. 5B) and therefore postdate the last connection between the rivers and the canyon head.

\subsection{3- Internal seismic facies and their lithologic significance}

The canyon head displays three major seismic facies, organized into different geomorphic features: 
Parallel, medium- to high-amplitude, continuous reflections (seismic facies 1) correspond to the most ubiquitous seismic facies (Fig. 9A). They form thick (from a few meters to several tens of meters) seismic sequences; in some cases, the reflections have a sigmoidal shape on both sides of buried channels, forming channel-levee systems from a few hundred meters to $2 \mathrm{~km}$ wide, confined within the canyon head (see below). Piston and interface cores retrieved from the shallowest part of this seismic facies exhibit, below $<1 \mathrm{~m}$ of unconsolidated (and probably mobile) Holocene mud drape, stiff clayey silts with intercalated sand beds interpreted as turbidites and hemipelagites (Gaudin et al., 2006). The sand fraction contains a large variety of shallow water (reworked) species.

\section{High-amplitude, chaotic seismic facies and (buried) channels (seismic facies 2)}

Several buried channelized features are observed throughout the canyon head. The infill of these channels is generally a distinct chaotic seismic facies (Fig. 9A) (high-amplitude, low continuity, sometimes hyperbolic reflections) very similar to the High Amplitude Reflections (HAR) described in deep-sea fans (i.e. on the Amazon fan, Flood et al. (1991)). When visible, the infill of the recent axial incision also presents a similar chaotic seismic facies (Fig. 9B). Shallow cores within the infill consist of structureless sandy mud or, more rarely, muddy sand (Gaudin et al., 2006). These channels appear as both erosional and depositional (aggradational) features, forming distinct channel-levee systems together with parallel seismic facies.

Medium- to low-amplitude, structureless or chaotic seismic facies (Mass Transport DepositsMTDs) (seismic facies 3)

A very distinct seismic facies corresponds to medium- to low-amplitude, structureless or chaotic reflections (Fig. 9C). On strike sections, they form sub-horizontal units from a few meters to more than 20 m thick, separated from parallel/continuous seismic facies by highamplitude bounding surfaces, the lower surface being generally erosional (Fig. 9C). These 
sediment bodies have not been reached by cores, but they can be confidently interpreted as mass transport deposits (MTDs), similar to those described for instance on the Mississippi (Weimer, 1989) and Amazon fans (Piper et al., 1997) or in outcrops in Italy (Di Celma et al., 2013; 2014). In general, such seismic facies correspond either to slumped deposits or to the product of laminar gravity flows, such as debrites (i.e., on the Amazon Fan, Normark et al. (1997). These features are particularly developed beneath the western terrace of the canyon head, where three main MTDs can be recognized (Fig. 10). The two main MTDs (labelled MTD2 and MTD3) are large enough to be mapped. They are 1.2 to $2 \mathrm{~km}$ wide, $6 \mathrm{~km}$ long, with their long axis oriented in the same direction as the canyon (NNW/SSE). They terminate updip at a depth of $-180 \mathrm{~m}$ and pinch out seaward at a depth of $450 \mathrm{~m}$ (Fig. 11).

\section{Lateral accretional/aggradational seismic facies}

In addition to the three major seismic facies/geomorphic features that are localized within the canyon head, the outer shelf displays a distinct type of incised channel, truncating forced- regressed shoreface deposits of the MIS 3/MIS 2 (Fig. 12A). Instead of being chaotic, the infill displays lateral accretion and aggradation geometries (Fig. 12A). This facies is restricted at present water depths comprised between 100 and $120 \mathrm{~m}$ (Fig. 12B). In some cases, it overlies very deeply incised channels with chaotic seismic facies, suggesting a genetic link between these two facies (Fig. 12B). This lateral accretional/aggradational seismic facies might be interpreted either as:

the infill of an ancient sinuous axial incision, as observed in confined channel systems offshore of Angola (Lateral Accretion Packages, LAPs, Abreu et al. (2003)), or

the infill of a fluvial or deltaic meandering distributary. 


\section{3- Distribution and ages of buried channels}

The dense grid of 2D-seismic profiles allows us to map the main buried geomorphic features in the canyon head and around the canyon rims. A network of 13 buried channels was identified within the Bourcart canyon head. However, on the shelf and landward of the $100 \mathrm{~m}$ contour line, it was impossible to track buried channels on seismic profiles, either because of the high amount of ensuing erosion and/or because of low incision due to a lower gradient.

On the basis of the available time constraints and considering their stratigraphic and geographic position, three groups of channels were identified.

Group 1 (Figs. 13A and 14A) includes buried channels located in the central part of the canyon head. On the basis of seismic correlations, a first phase of formation of confined channel-levees appears immediately below surface D63f (Fig. 13B). Evidence of renewed channel-levee functioning appears around or after surface D64r, which corresponds to a distinct erosion surface on the shelf as well as in the shallowest part of the canyon head. These channel-levee systems are connected to shelf fluvial erosions and were active until ca. 19 cal ka BP, which corresponds to the beginning of the period of deposition and cementation at the top of the channels.

Group 2 (Figs. 13A and 14B) comprises four buried channels, located on the eastern side of the canyon head. The channels have the same seismic characters as those of group 1 , but they are smaller and were active only during a short interval between 22.5 and 21.5 cal ka BP (surfaces D67 and D70s) (Fig. 13A).

Group 3 (Figs. 13A and 14C), comprises four channels located on the western side of the Bourcart canyon head. They display a distinct channel-levee organization embedded 
between D70s and the seafloor. They are younger than $21.5 \mathrm{cal}$ ka BP and older than the axial incision (which cuts through them; Fig. 13A) i.e. ca. 19 cal ka BP (see below).

The most recent channel (Fig. 14D) is the axial incision described in section 5.1. It corresponds to the last phase of incision before the disconnection of the canyon head from the fluvial system(s). It formed earlier than $21.5 \mathrm{cal}$ ka BP, as it cuts across seismic surface D70s. The axial incision was no longer active around $19 \mathrm{cal}$ ka BP, as demonstrated by the time constraint from the beachrocks (Fig. 3 and 5).

The central channels represent the first phase of fluvial/canyon connection, starting around $40 \mathrm{ka}$ cal BP, when global sea-level was in the order of $-95 \mathrm{~m}$ (Fig. 14A to 14D). A possible connection during MIS 4 (around $60 \mathrm{ka} \mathrm{BP}$ ) cannot be ruled out, but temporal resolution is very low for this interval (see discussion). The period of disconnection is around 19 cal ka $\mathrm{BP}$, in relation with an increased rate of sea-level rise following the LGM.

\section{4- Quantitative estimates of the geomorphic evolution of the canyon head during the last glacial cycle}

Major seismic surfaces defined in section 5.2 were mapped throughout the canyon head using SMT Kingdom Suite ${ }^{\mathrm{TM}}$ software. From this interpretation, several isobath maps were computed within a polygon covering an area of $98 \mathrm{~km}^{2}$, ranging from $100 \mathrm{~m}$ to about $400 \mathrm{~m}$ water depth. The isopach maps of the seismic units bounded by these surfaces were also computed.

\subsection{1- Preserved sediment volumes in the Bourcart canyon head}

The volume of sediment preserved in the canyon head during the last Glacial/Deglacial period (between seismic surface D60m and the modern sea floor) is ca. $7.04 \mathrm{~km}^{3}$. More precisely, 3 isopach maps were computed to highlight canyon evolution in relation with major phases of relative sea-level changes (Fig. 15). 
A- The preserved sediment volume corresponding to the interval between MIS 5.e (131 ka BP) and IS8 (37 cal ka BP) (seismic unit 1) are mainly concentrated in the deepest part of the study area (beyond 140 m present water depth), along the thalweg of the MIS 6 canyon (Fig. 15A). This unit is $35-50 \mathrm{~m}$ thick on average, with a volume of ca. $1.04 \mathrm{~km}^{3}$, i.e. $15 \%$ of the total preserved volume for the last cycle (deposited in 94 kyr).

$\boldsymbol{B}$ - Seismic unit 2 corresponds to the interval deposited between IS8 and the end of the LGM (Fig. 15B). This unit is up to $100 \mathrm{~m}$ thick, with a volume of ca. $3.48 \mathrm{~km}^{3}$, accounting for $50 \%$ of all the sediment preserved during the last glacial cycle. It can be divided into three sub-units (U2a, U2b, and U2c) that account respectively for 12,12 and $26 \%$ of the preserved sediment volume. U2a and U2b are topped by D64f and D65f, respectively, the flooding surfaces following phases of sea-level falls are terminated by Heinrich Stadials 3 and 2, respectively. The upper parts of these two units display major MTDs (MTD2 and MTD3, respectively).

$\boldsymbol{C}$ - The upper seismic unit U3 corresponds to the interval between the LGM sequence boundary (D70s) and the cessation of sedimentation at the canyon head, around 17 cal ka BP (Fig. 15C). It reaches up to $90 \mathrm{~m}$ in thickness, especially along the western flank of the canyon, probably in relation with a source from the west. The erosional impact of the axial incision is clearly visible on the isopach map. The total volume of this interval spanning 4,500 years is ca. $2.52 \mathrm{~km}^{3}$, accounting for $35 \%$ of the overall preserved deposits. This unit is marked both by aggrading turbiditic channels topped by lateral accretional/aggradational seismic facies, and overall progradation (despite the fact that it formed in a context of relative sea-level rise) due to the infill of the available space of the canyon head. 


\subsection{2- Paleogeographic evolution of the canyon head}

Along each seismic surface, the "200 m" water depth contour line roughly represents, after correction of the subsidence, the shelf edge. The comparison of this $200-\mathrm{m}$ contour line at different periods shows a seaward migration of the canyon head of about $3 \mathrm{~km}$ between MIS 5.e and the present day (about $131 \mathrm{kyr}$ ) (Fig. 16). During the same time interval, the canyon rims remained at the same position despite local mass failures.

\section{5- Discussion}

\section{1- Chronology of fluvial-canyon connections in the Bourcart canyon head}

On the basis of chrono-stratigraphic correlations with borehole and core data, the history of the fluvial connections with the Bourcart canyon head during the last glacial cycle can be summarized as follow:

1- Episodic connection during MIS 3 occurred, during a pronounced sea-level fall that terminated around $40 \mathrm{ka} \mathrm{BP}$, at the time of HS4 (Fig. 17). This event corresponds to the lowest sea level during the entire MIS 3 and coincides in the canyon head with an early phase of formation of buried channel-levees. They are topped by D63f which is, in the canyon head, a conformable surface corresponding probably to a condensed level due to fluvial disconnection, in response to the rapid sea-level rise (of about $30 \mathrm{~m}$ according to Arz et al., (2007)) that occurred during IS8. Such a condensed interval formed along the nearby canyon interfluve, as described at borehole PRGL1 by Sierro et al. (2009). We cannot exclude an earlier connection during MIS 4, but very little sediment from this period is preserved in the canyon head, preventing any precise stratigraphic correlation. 


\section{2- Major and continuous connections of several fluvial systems occurred}

during MIS 2. Channel-levee development in the canyon head resumed during two phases of sea-level fall, contemporaneous with surface D64r (around 28 ka cal BP) and D70s, the sequence boundary of the Last Glacial Maximum dated around $21.5 \mathrm{ka}$ cal BP. The first period marks the onset of MIS 2 and an acceleration of global sea-level fall, with an eastern fluvial system reaching the canyon head. D64r is also the lower boundary of MTD2, one of the two major mass transport deposits observed in the canyon head. It marks the low sea-level reached at HS3, whereas the second MTD (MTD3) marks the lowest sea-level at HS2.

3- The cessation of turbiditic activity is post-dated by the "Pierres de Sete" beachrocks that formed between 19 and $18 \mathrm{cal}$ ka BP. There is some evidence of an early phase of rapid sea-level rise after the LGM, between ca. 20 and 19 ka $\mathrm{BP}$, followed by a period of stillstand or slow rise between ca. 19-18 ka BP (Lambeck et al., 2014; Yokoyama et al., 2000). The rapid rise of sea level, called Meltwater Pulse 19 k (Clark et al., 2004; Hanebuth et al., 2009) might explain fluvial/canyon disconnection, whereas the period of stillstand would have favored thecementation of a transgressive shoreline (located landward with respect to the LGM shoreline). The early phase of global sea-level rise is at the origin of a sediment wedge forming an aggradational/progradational parasequence that accounts for $35 \%$ of the total canyon infill, deposited in only $4.5 \mathrm{kyr}$ (seismic unit U3). The fact that progradation kept pace with sea-level rise can be explained by the increased flux of sediment delivered during this early deglacial phase of mountain glacier melting, as also observed in the Rhone canyon (Lombo Tombo et al., 2015). 


\section{2- Hyperpycnal flows in the Bourcart canyon head during LGM}

The (meandering) axial incision observed in the Bourcart canyon head (and other canyon heads such as the Herault 1 and 2) pinches out at a present water depth of $120 \mathrm{~m}$; this implies that it was directly connected to the Agly River when the relative seal level (RSL) was in the order of $-115 \mathrm{~m}$, at the time of activity of the axial incision. The very shallow water depth of the axial incision during its activity also implies that the high-density turbulent gravity flows at the origin of the turbiditic channel had to be generated in the river, or at the river mouth, as a hyperpycnal flow (Mulder et al., 1997; Mulder and Syvitski, 1995) that plunged downslope, generating depositional/erosional meanders and confined levees by overbank flow. A similar process was proposed by Chiang and $\mathrm{Yu}$ (2008) to explain the meandering of the Kaoping Canyon off SW Taiwan where hyperpycnal flows are presently monitored (see the review by Puig et al. (2014)). Note, however, that some hyperpycnal flows have been observed in canyons without meandering patterns, such as in the Golo systems (Gervais et al., 2006), the Var canyon (Khripounoff et al., 2009) or the Eel canyon (Drexler et al., 2006; Imran and Syvitski, 2000). However, in the case of the Var, where hyperpycnal flows were monitored over a 2-year period (Khripounoff et al., 2012), the absence of meanders in the canyon head might be explained by the fact that it is carved into very consolidated Messinian and Pliocene deposits (Savoye and Piper, 1991) It can be also noted that the lack of precise (multi-beam) bathymetric data in several canyon heads where hyperpycnal flows have been recorded (e.g.(Kineke et al., 2000)) prevents any further interpretation of the genetic link between such turbidity flows and meanders.

Today, rivers such as the Tech, Aude and Agly are known for catastrophic flash floods and the delivery of large amounts of sediment to the sea, despite damming 
and civil engineering work in the coastal plain. During the onset of the Deglaciation, global warming, increased rainfall and flushing of sediments eroded by mountain glaciers favored the formation of such hyperpycnal flows within the Mediterranean fluvial systems. The presence of pebbles of fluvial origin within the paleo-Bourcart canyon head, situated $5 \mathrm{~km}$ from our study area (Bassetti et al., 2008), is further evidence of the capacity of small Mediterranean coastal streams to transport large amounts of sediment of all sizes to the shelf edge during catastrophic events, despite the low gradient $\left(0.1^{\circ}\right)$ and long distance (about $60 \mathrm{~km}$ at this time) from the foothills of the mountains.

In the nearby Petit Rhone canyon, turbidites interpreted as hyperpycnites (Mulder et al., 2003) have been cored (Lombo Tombo et al., 2015), suggesting that this process occurred at the end of the LGM. These authors showed that the hyperpycnal processes started before 20 cal ka BP (the age at the bottom of their studied cores) and ceased around 19.5 cal ka BP, i.e. when the river was disconnected from the canyon head. In the Bourcart canyon, the period of activity of the axial incision is about the same, between 21.5 and 19 ka. If the Rhone experienced hyperpycnal processes during or at the end of the LGM, it is likely that the small rivers of the western rim of the Gulf of Lions (especially the Tet, Tech and Agly), which are typical Mediterranean mountain rivers with flash floods occurring during fall and spring, were prone to generating hyperpycnal flows, as modeled for the modern Tet river by Kettner and Syvitski (2009).

\section{3- Relation between MTDs and Bond Cycles}

Bond cycles (Alley, 1998) are bundles of millennial-scale climate changes (called Dansgaard-Oeschger cycles) initially described in the North Atlantic for the last glaciation within a prolonged cooling trend, marked by "abrupt shifts to markedly warm interstadials" 
(Bond et al., 1993). Their coldest part is marked by a Heinrich event (Fig. 17). These cycles are important from a stratigraphic point of view because the rapid warmings correspond to important (10-30 m) and rapid (up to $4 \mathrm{~cm}_{\mathrm{yr}}{ }^{-1}$ ) periods of sea-level rise, lasting less than 500 years (Arz et al., 2007; Siddall et al., 2003). As mentioned previously, seismic surfaces D63f, D64f and D65f are the flooding surfaces bounding the three major regressive parasequences related to the Bond Cycles of the last glacial period, between 40 and 25 cal ka BP. They were identified at the position of borehole PRGL1 (Sierro et al., 2009) and PRGL2 (Bassetti et al., 2008) and mapped throughout the study area. In contrast with classical parasequences (Van Wagoner et al., 1990), which form within transgressive systems tracts, these parasequences are downstepping parasequences formed within the falling stage systems tract (in the sense of Plint and Nummedal, 2000), during an overall sea-level fall. The fact that the two major MTDs (MTD2 and MTD3) observed in the canyon head are situated immediately below flooding surfaces D64f and D65f suggests that they occurred at the end of the phases of sea-level fall of the respective Bond cycles, the flooding surfaces representing condensed intervals due to decreased sediment accumulation (Fig. 17). These phases of sea-level falls are prone to slope failure because the sediment accumulation rate progressively increased during each Bond cycle, in relation with the decreasing distance of sediment sources. Very large sediment delivery of unconsolidated fine-grained sediment is therefore the primary explanation for slope failure by oversteepening of the canyon flanks at the end of phases of pulsed sea-level fall. An additional factor might be the lowering of the storm-wave base (and related storm-triggered mass wasting), and possibly the exsolution of free gas contained in organic-rich clinoforms of the shelf-edge deltas. This latter process has been demonstrated to be an important factor in the formation of pockmarks situated along the Bourcart/Herault interfluve (Lafuerza et al., 2009; Riboulot et al., 2014). 


\section{6- Concluding remarks}

The direct connection of the Bourcart canyon with a river was temporarily established as early as ca. 40 ka BP, but most of the strata preserved in the canyon head were deposited between ca. 28 and 19 cal ka BP. This period corresponds to a drastic increase of the sediment accumulation rate, which accounts for $73 \%$ of the preserved sediments deposited during the last glacial cycle. From our study, several local and general conclusions can be drawn about the complex relationships between canyon fills, fluvial systems, and the influence of sea-level and climate changes:

1- Canyons can be depositional systems. From a geological perspective, canyons situated along (deltaic) subsiding margins with high sediment supply are, in the long term, depositional features and not only "by-pass" zones. During the last glacial cycle, the Bourcart canyon head shifted seaward by about $3 \mathrm{~km}$. This is the result of the overall depositional (not erosional) nature of this canyon, and of the overall progradation of the margin, which was rebuilt and migrated about $50 \mathrm{~km}$ after the end of the Messinian Salinity Crisis (Lofi et al., 2003). Similar observations of canyon upbuilding and outbuilding have been made elsewhere, for instance on the Ebro Margin (Field and Gardner, 1990; Gerber et al., 2009) or the Gabon Margin (Rasmussen, 1994; 1997).

2- The penultimate sequence boundary (MIS 6.a) forms the major erosion surface underlying the Bourcart canyon fill. It is overlain by both forced-regressive and progradational/aggradational parasequences linked to glacio-eustatic Bond cycles (ca. $7 \mathrm{kyr}$ ) formed successively during the Last Glacial Maximum. These parasequences display confined channel-levees and are topped by MTDs deposited at the end of each cycle (in relation with increased sediment flux at that time). The bounding surfaces between these parasequences are condensed surfaces linked to 
sediment starvation. Interestingly, a similar stratigraphic motif is observed on outcrops from uplifted Pliocene-early Pleistocene canyons of the Marche-Apennine and Abruzzi foredeep (Di Celma, 2011; Di Celma et al., 2010; 2014). A similar architecture is likely to exist in other canyons around the world, at least for periods dominated by Glacial/Interglacial cycles (Ice House World) where both climate and sea level are important controlling parameters.

3- Hyperpycnal flows during the early Deglaciation are the most likely process for explaining the presence of meanders directly connected to paleo-fluvial channels at the Bourcart and Herault canyon heads (and elsewhere in the Gulf of Lions). During the onset of the Deglaciation, global warming, increased rainfall and flushing of sediments eroded by mountain glaciers favored the formation of such hyperpycnal flows within the Mediterranean fluvial systems such as the Po (Asioli et al., 2001) and the Rhone (Lombo Tombo et al., 2015).

4- Shallow-water confined channel-levee systems form the bulk of the canyon head infill. Increasing accommodation and high sediment fluxes due to deglacial sea-level rise favored the deposition and preservation of shallow-water confined channel-levee systems. Because of the overall progradational nature of these deposits, 2D seismic profiles display deeply incised channels with chaotic seismic facies (gravity deposits within a turbiditic channel) topped by aggradational/progradational facies of unknown origin (fluvio-deltaic or turbiditic). More generally, such a stratigraphic motif is likely to be preserved in other Quaternary canyons and in the rock record.

5- The canyon/river dilemma. The large number of canyons along continental margins, if compared to relatively limited numbers of large rivers onshore, has fueled the idea that the origin of several canyons is not linked to the presence of fluvial systems. At least in the case of the Gulf of Lions, this discrepancy can be explained by the fact 
that all canyons are not active simultaneously during each (glacio-) eustatic cycle. Canyons connected during or around the Last Glacial Maximum are identifiable, in our study area and elsewhere (Lastras et al., 2009), by the presence of (often meandering) axial incisions cutting across the main thalweg of the canyon. In contrast, canyon heads that were not connected to fluvial systems experienced, during the same time interval, hemipelagic sedimentation fed by sediment plumes transported by the general anti-clockwise circulation, or starvation (and formation of condensed intervals). The shift of shelf-edge delta-lobes during one single glacioeustatic cycle, or different fluvial pathways during subsequent eustatic cycles, are at the origin of the large number of canyons indenting the margin. This does not apply to some very large fluvial systems, where very high sediment fluxes can maintain fluvial/canyon connections over a longer period through retrogressive failure. As a result, such systems deeply incised the shelf (Rhone, Danube, Mississippi, GangesBrahmaputra...) or even remained connected during the entire eustatic cycle (Congo).

\section{Acknowledgements}

This research was made possible thanks to the very large seismic database obtained during numerous sea campaigns in the last decades, mainly aboard R/V "Le Suroit" and R/V “L'Europe” (Basar 1, 2 and 3, Calmar-97 and 99, Marion, Strataform, Beachmed, Calimero and Rhosos cruises). The time constraints utilized here mainly come from the drilling operation conducted within the European project PROMESS 1 (contract EVR1-CT2002-40024) aboard the Fugro drilling vessel "Bavenit". Calypso piston cores were retrieved during the "Images 5" cruise aboard the "Marion Dufresne". The captains and crews of the vessels, as well as the scientific parties at sea and in the laboratories, are thanked for their contributions. Special thanks are due to Bertil Hebert for his technical 


\section{References}

Abreu, V., Sullivan, M., Pirmez, C., and Mohrig, D., 2003. Lateral accretion packages (LAPs): an important reservoir element in deep water sinuous channels: Marine and Petroleum Geology, v. 20, p. 631-648.

Alexandersson, T., 1972. Mediterranean beachrock cementation: marine precipitation of Mg-calcite, in Stanley, D. J., ed., The Mediterranean Sea: a natural sedimentation laboratory: Stroudsburg, Dowden, Hutchinson \& Ross, Inc., p. 203-223.

Alley, R. B., 1998. Icing the North Atlantic: Nature, v. 392, p. 335-337.

Arz, H. W., Lamy, F., Ganopolski, A., Nowaczyk, N., and Pätzold, J., 2007. Dominant Northern Hemisphere climate control over millennial-scale glacial sea-level variability: Quaternary Science Reviews, v. 26, p. 312-321.

Asioli, A., Trincardi, F., Lowe, J. J., Ariztegui, L., and Oldfield, F., 2001. Sub-millennial scale climatic oscillations in the central Adriatic during the Lateglacial: palaeoceanographic implications: Quaternary Science Reviews, v. 20, p. 1201-1221.

Bassetti, M. A., Berné, S., Jouet, G., Taviani, M., Dennielou, B., Flores, J. A., Gaillot, A., Gelfort, R., Lafuerza, S., and Sultan, N., 2008. The 100-ka and rapid sea level changes recorded by prograding shelf sand bodies in the Gulf of Lions (western Mediterranean Sea): Geochemistry, Geophysics, Geosystems, v. 9, no. 11. 10.1029/2007GC001854/:

Bassetti, M. A., Jouet, G., Dufois, F., Berné, S., Rabineau, M., and Taviani, M., 2006. Sand bodies at the shelf edge in the Gulf of Lions (Western Mediterranean): Deglacial history and modern processes: Marine Geology, v. 234, no. 1-4, p. 93-109. 10.1016/j.margeo.2006.09.010:

Baztan, J., Berné, S., Olivet, J. L., Rabineau, M., Aslanian, D., Gaudin, M., Réhault, J. P., and Canals, M., 2005. Axial incision: The key to understand submarine canyon evolution (in the western Gulf of Lion): Marine and Petroleum Geology, v. 22, no. 6-7, p. 805-826. 10.1016/j.marpetgeo.2005.03.011:

Berger, G. M., Fonteilles, M., Leblanc, D., Clauzon, G., Marchal, J.-P., and Vautrelle, C., 1993. Notice explicative de la carte géologique de la France au 1/50.000, feuille de Rivesaltes (1090), Orléans, BRGM.

Berné, S., Jouet, G., Bassetti, M. A., Dennielou, B., and Taviani, M., 2007. Late Glacial to Preboral sea-level rise recorded by the Rhone deltaic system (NW Mediterranean): Marine Geology, v. 245, p. 65-88.

Berné, S., Loubrieu, B., and Equipe Calmar, 1999. Canyons et processus sédimentaires récents sur la marge occidentale du golfe du Lion. Premiers résultats de la campagne Calmar: Comptes Rendus de l'Académie des Sciences, v. 328, p. 471-477.

Biscara, L., Mulder, T., Martinez, P., Baudin, F., Etcheber, H., Jouanneau, J. M., and Garlan, T., 2011. Transport of terrestrial organic matter in the Ogooué deep sea turbidite system (Gabon): Marine and Petroleum Geology, v. 28, p. 1061-1072.

Blum, M. D., and Törnqvist, T. E., 2000. Fluvial responses to climate and sea-level change: a review and look forward: Sedimentology, v. 41, p. 2-48.

Bond, G., Broecker, W., Johnsen, S., McManus, J., Labeyrie, L., Jouzel, J., and Bonani, G., 1993. Correlations between climate records from North Atlantic sediments and Greenland ice: Nature, v. 365, p. 143-147.

Boyd, R., Ruming, K., Goodwin, I., Sandstrom, M., and Schröde-Adams, C., 2008. Highstand transport of coastal sand to the deep ocean: A case study from Fraser Island, southeast Australia: Geology, v. 36, no. 1, p. 15-18.

Catuneanu, 0., 2006. Accomodation and shoreline shifts, in Elsevier, ed., Principles of sequence stratigraphy.

Catuneanu, O., Abreu, V., Bhattacharya, J. P., Blum, M. D., Dalrymple, R. W., Eriksson, P. G., Fielding, C. D., Fisher, W. L., Galloway, W. E., Gibling, M. R., Giles, K. A., Holbrook, J. M., Jordan, R., Kendall, C. G. S. C., Macuda, B., Martinsen, O. J., Miall, A. D., Neal, J., Nummedal, D., Pomar, L., Posamentier, H. W., Pratt, B. R., Sarg, J. F., Shanley, K. W., Steel, R. J., Strasser, A., Tucker, M. E., and Winker, C., 2009. Towards the standardization of sequence stratigraphy: Earth Science Reviews, v. 92, p. 1-33.

Chiang, C.-S., and Yu, H.-S., 2008. Evidence of hyperpycnal flows at the head of the meandering Kaoping Canyon off SW Taiwan: Geo-marine Letters, v. 28, no. 3, p. 161-169.

Clark, P. U., McCabe, A. M., Mix, A. C., and Weaver, A. J., 2004. Rapid rise of sea level 19,000 years ago and its global implications: Science, v. 304, no. 5674, p. 1141-1144.

Covault, J. A., Normark, W. R., Romans, B. W., and Graham, S. A., 2007. Highstand fans in the California borderland: The overlooked deep-water depositional systems: Geology, v. 35, no. 9, p. 783-786. 10.1130/g23800a.1: 
Daly, R. A., 1936. Origin of submarine canyons: American Journal of Science, v. 31, p. 401-420.

Dennielou, B., 2007. Depth vs. velocity and two-way traveltime data of the Hole PRGL1-4: Institut francais de recherche pour l'exploitation de la mer - Centre de Brest 10.1594/PANGAEA.610088:

Di Celma, C., 2011. Sedimentology, architecture, and depositional evolution of a coarse-grained submarine canyon fill from the Gelasian (early Pleistocene) of the Peri-Adriatic basin, Offida, central Italy: Sedimentary Geology, v. 238, p. 233-253.

Di Celma, C., Cantalamessa, G., and Didaskalou, P., 2013. Stratigraphic organization and predictability of mixed coarse-grained and fine-grained successions in an upper slope Pleistocene turbidite system of the PeriAdriatic basin: Sedimentology, v. 60, no. 3, p. 763-799. 10.1111/j.1365-3091.2012.01359.x:

Di Celma, C., Cantalamessa, G., Didaskalou, P., and Lori, P., 2010. Sedimentology, architecture, and sequence stratigraphy of coarse-grained, submarine canyon fills from the Pleistocene (Gelasian-Calabrian) of the Peri-Adriatic basin, central Italy: Marine and Petroleum Geology, v. 27, p. 1340-1365.

Di Celma, C., Teloni, R., and Rustichelli, A., 2014. Large-scale stratigraphic architecture and sequence analysis of an early Pleistocene submarine canyon fill, Monte Ascensione succession (Peri-Adriatic basin, eastern central Italy): International Journal of Earth Science, v. 103, p. 843-875.

Drexler, T. M., Nittrouer, C. A., and Mullenbach, B. L., 2006. Impact of local morphology on sedimentation in a submarine canyon, ROV studies in Eel canyon, northern Califormai, U.S.A: Journal of Sedimentary Research, v. 76, p. 839 - 853.

Emery, K. O., 1968. Relict sediments on the continental shelves of the world: American Association of Petroleum Geologists Bulletin, v. 52, p. 445-464.

Farre, J. A., McGregor, B. A., Ryan, W. B. F., and Robb, J. M., 1983. Breaching the shelfbreak: passage from youthful to mature phase in submarine canyon evolution, in G.T., S. D. J. a. M., ed., The shelfbreak: critical interface on continental margins, SEPM, p. 25-39.

Field, M., E., and Gardner, J. V., 1990. Pliocene-Pleistocene gowth of the rio Ebro margin, northeast Spain: A prograding-slope model: Geological Society of American Bulletin, v. 102, p. 721-733.

Flood, R. D., Manley, P. L., Kowsmann, R. O., Appi, C. J., and Pirmez, C., 1991. Seismic facies and late Quaternary growth of Amazon submarine fan, in Weimer, P., and Link, M. H., eds., Seismic facies and sedimentary processes of modern and ancient submarine fans: New York, Springer-Verlag, p. 415-433.

Frigola, J., Canals, M., Cacho, I., Moreno, A., Sierro, F. J., Flores, J. A., Berné, S., Jouet, G., Dennielou, B., Herrera, G., Pasqual, C., Grimalt, J. O., Galavazi, M., and Schneider, R., 2012. A 500 kyr record of global sea-level oscillations in the Gulf of Lion, Mediterranean Sea: new insights into MIS 3 sea-level variability: Climate of the Past, v. 8, no. 3, p. 1067-1077. 10.5194/cp-8-1067-2012:

Galloway, W., Dingus, W., and Paige, R., 1991. Seismic and depositional facies of Paleocene-Eocene Wilcox Group submarine canyon fills, northwest Gulf Coast, USA, Seismic facies and sedimentary processes of submarine fans and turbidite systems, Springer, p. 247-271.

Gaudin, M., Berné, S., Jouanneau, J. M., Palanques, A., Puig, P., Mulder, T., Cirac, P., Rabineau, M., and Imbert, P., 2006. Massive sand beds attributed to deposition by dense water cascades in the Bourcart canyon head, Gulf of Lions (northwestern Mediterranean Sea): Marine Geology, v. 234, no. 1-4, p. 111-128. 10.1016/j.margeo.2006.09.020:

Gensous, B., and Tesson, M., 2003. L'analyse des dépôts postglaciaires et son application à l'étude des séquences de dépôt du Quaternaire terminal sur la plate-forme au large du Rhone (golfe du Lion): Bulletin de la société Géologique de France, v. 174, no. 4, p. 401-419.

Gerber, T. P., Amblas, D., Wolinsky, M. A., Pratson, L. F., and Canals, M., 2009. A model for the long-profil shape of submarine canyons: Journal of geophysical research, v. 114.

Gervais, A., Mulder, T., Savoye, B., and Gonthier, E., 2006. Sediment distribution and evolution of sedimentary processes in a small sandy turbidite system (Golo system, Mediterranean Sea): implications for various geometries based on core framework: Geo-marine Letters, v. 26, p. 373 - 395.

Hanebuth, T. J. J., Stattegger, K., and Bojanowski, A., 2009. Termination of the Last Glacial Maximum sea-level lowstand: The Sunda-shelf data revisited: Global and Planetray Change, v. 66, p. 76-84.

He, Y., Xie, X., Kneller, B. C., Wang, Z., and Li, X., 2013. Architecture and controlling factors of canyon fills on the shelf margin in the Qiongdongnan Basin, northern South China Sea: Marine and Petroleum Geology, v. 41, p. 264-276. 10.1016/j.marpetgeo.2012.03.002:

Hemming, S. R., 2004. Heinrich events: Massive late Pleistocene detritus layers of the North Atlantic and their global climate imprint: Review of Geophysics, v. 42, p. 43.

Imran, J., and Syvitski, J. P. M., 2000. Impact of extreme river events on the coastal ocean: Oceanography, v. 13, no. 3, p. 85 - 92.

Jobe, Z. R., Lowe, D. R., and Uchytil, S. J., 2011. Two fundamentally different types of submarine canyons along the continental margin of Equatorial Guinea: Marine and Petroleum Geology, v. 28, no. 3, p. 843-860. 
Jouet, G., Berné, S., Rabineau, M., Bassetti, M. A., Bernier, P., Dennielou, B., Sierro, F. J., Flores, J. A., and Taviani, M., 2006. Shoreface migrations at the shelf edge and sea-level changes around the Last Glacial Maximum (Gulf of Lions, NW Mediterranean): Marine Geology, v. 234, no. 1-4, p. 21-42. 10.1016/j.margeo.2006.09.012:

Kettner, A. J., and Syvitski, J. P. M., 2009. Fluvial response to environmental perturbations in the Northern Mediterranean since the Lsta Glacial Maximum: Quaternary Science Reviews, v. 28, p. 2386-2397.

Khripounoff, A., Crassous, P., Lo Bue, N., Dennielou, B., and Silva Jacinto, R., 2012. Different types of sediment gravity flows detected in the Var submarine canyon (northwestern Mediterranean Sea): Progress in Oceanography, v. 106, p. 138-153.

Khripounoff, A., Vangriesheim, A., Crassous, P., and Etoubleau, J., 2009. High frequency of sediment gravity flow events in the Var submarine canyon (Mediterranean Sea): Marine Geology, v. 263, p. 1 - 6.

Kineke, G. C., Woolfe, K. J., Kuehl, S. A., Milliman, J. D., Dellapenna, T. M., and Purdon, R. G., 2000. Sediment export from the Sepik River, Papua New Guinea: evidence for a divergent sediment plume: Continental Shelf Research, v. 20, no. 16, p. 2239-2266.

Laberg, J. S., Guidard, S., Mienert, J., Vorren, T. O., Halfidason, H., and Nygard, A., 2007. Morphology and morphogenesis of a high-latitude canyon; the Andoya Canyon, Norwegian Sea: Marine Geology, v. 246, p. 68-85.

Lafuerza, S., Sultan, N., Canals, M., Frigola, J., Berné, S., Jouet, G., Galavazi, M., and Sierro, F. J., 2009. Overpressure within upper continental slope sediments from CPTU data, Gulf of Lion, NW Mediterranean Sea: International Journal of Earth Science, v. 98, no. 4, p. 751-768.

Lambeck, K., Rouby, H., Purcell, A., Sun, Y., and Sambridge, M., 2014. Sea level and global ice volumes from the Last Glacial Maximum tu the Holocene: Proceedings of the National Academy of Science of the United States of America, v. 111, no. 43, p. 15296-15303.

Lastras, G., Acosta, J., Munoz, A., and Canals, M., 2011. Submarine canyon formation and evolution in the Argentine

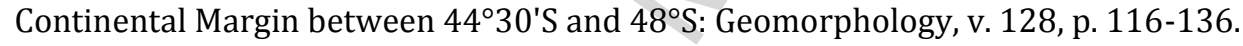

Lastras, G., Arzola, R. G., Masson, D. G., Wynn, R. B., Huvenne, V. A. I., Huhnerbach, V., and Canals, M., 2009. Geomorphology and sedimentary features in the cnetral Portuguese submarine canyons, Western Iberian margin: Geomorphology, v. 103, p. 310-329.

Lisiecki, L. E., and Raymo, M. E., 2005. A Pliocene-Pleistocene stack of 57 globally distributed benthic $\delta 180$ records: Paleoceanography, v. 20, no. 1, p. n/a-n/a. 10.1029/2004pa001071:

Lo Iacono, C., Sulli, A., and Agate, M., 2013. Submarine canyons of north-western Sicily (Southern Tyrrhenian Sea): Variability in morphology, sedimentary processes and evolution on a tectonically active margin: Deep-Sea Research Part II, v.?, no.?, p.?

Lofi, J., Rabineau, M., Gorini, C., Berné, S., Clauzon, G., De Clarens, P., Tadeu Dos Reis, A., Mountain, G. S., Ryan, W. B. F., Steckler, M. S., and Fouchet, C., 2003. Plio-Quaternary prograding clinoform wedges of the western Gulf of Lion continental margin (NW Mediterranean) after the Messinian Salinity Crisis: Marine Geology, v. 198, p. 289-317.

Lombo Tombo, S., Dennielou, B., Berné, S., Bassetti, M. A., Toucanne, S., Jorry, S., Jouet, G., and Schneider, R., 2015. Sea-level control on turbiditic activity in the Rhone canyon and the upper fan during the Last Glacial Maximum and early Deglacial: Sedimentary Geology.

Mazières, A., Gillet, H., Castelle, B., Guyot, C., and Mallet, C., 2013. Last decade relationship between longshore drift and the head of the canyon of Capbreton (SW France): descriptive and numerical approaches.: Geophysical Reasearch Abstracts, v. 15, no. EGU2013-375.

Mitchum, R. M., Vail, P. R., and Thompson, S., 1977. Seismic stratigraphy and global changes of sea level: Part 6. Stratigraphic interpretation of seismic reflection patterns in depositional sequences, seismic stratigraphy-applications to hydrocarbon exploration, AAPG.

Mountain, G. S., Damuth, J. E., McHugh, C. M. G., Lorenzo, J. M., and Fulthorpe, C. S., 1996. Origin, reburial, and significance of a middle Miocene canyon, New Jersey continental slope: Proceedings of the Ocean Drilling Program, Scientific Results, v. 150, p. 1-10.

Mulder, T., Savoye, B., and Syvitski, J. P. M., 1997. Numerical modelling of a mid-sized gravity flow: the 1979 Nice turbidity current (dynamics, processes, sediment budget and seafloor impact): Sedimentology, v. 44, p. 305-326.

Mulder, T., and Syvitski, J. P. M., 1995. Turbidity currents generated at river mouths during exceptional discharges to the world oceans: The journal of Geology, v. 103, no. 3, p. 285-299.

Mulder, T., Syvitski, J. P. M., Migeon, S., Faugères, J.-C., and Savoye, B., 2003. Marine hyperpycnal flows: initiation, behavior and related deposits. A review: Marine and Petroleum Geology, v. 20, p. 861-882.

Nakajima, T., Kakuwa, Y., Yasudomi, Y., Itaki, T., Motoyama, I., Tomiyama, T., Machiyama, H., Katayama, H., Okitsu, O., Morita, S., Tanahashi, M., and Matsumoto, R., 2014. Formation of pockmarks and submarine canyons 
associated with dissociation of gas hydrates on the Joetsu Knoll, eastern margin of the Sea of Japan: Journal of Asian Earth Sciences, v. 90, p. 228-242.

Normark, W. R., Damuth, J. E., and Leg 155 Sedimentology Group, 1997. Sedimentary facies and associated depositional elements of the Amazon fan, in Flood, R. D., Piper, D. J. W., Klaus, A., and Peterson, L. C., eds., Proceedings of the Ocean Drilling Program, scientific results, Volume 155, p. 611-651.

Normark, W. R., and Piper, D. J. W., 1991. Initiation processes and flow evolution of turbidity currents: implications for the depositional record, From Shoreline to Abyss, Volume 46, SEPM Special publications, p. 209-230.

North Greenland Ice Core Project members, 2004. High resolution climate record of the nothern hemisphere reaching into the last interglacial period: Nature, v. 431, p. 147-151.

Piper, D. J. W., Pirmez, C., Manley, P. L., Long, D., Flood, R. D., Normak, W. R., and Showers, W., 1997. Mass-transport deposits of the Amazon fan: Proceedings of the Ocean Drilling Program, Scientific Results, v. 155, p. 109146.

Posamentier, H. W., and Allen, G. P., 1999. Siliciclastic sequence stratigraphy: concepts and applications., in SEPM, ed., Concept in Sedimentology and Paleontology, Volume 7, p. 210p.

Posamentier, H. W., Jervey, M. T., and Vail, P. R., 1988. Eustatic controls on clastic deposition I - Conceptual framework, Sea-level changes: an integrated approach, Volume Special publication 42: Tulsa, Oklahoma, USA, Society of ecomonic paleontologists and mineralogists, p. 109-124.

Pratson, L. F., and Coakley, B. J., 1996. A model for the headward erosion of submarine canyons induced by downslope-eroding sediment flows: Geological Society of American Bulletin, v. 108, no. 2, p. 225-234.

Pratson, L. F., Ryan, W. B. F., Mountain, G. S., and Twichell, D. C., 1994. Submarine canyon initiation by downslopeeroding sediment flows: Evidence in late Cenozoic strata on the New Jersey continental slope: Geological Society of American Bulletin, v. 106, p. 395-412.

Puig, P., Palanques, A., and Martin, J., 2014. Contemporary sediment-transport processes in submarine canyons: Annual Review of Marine Science, v. 6, no. 5, p. 1-25.

Rabineau, M., Berné, S., Aslanian, D., Olivet, J.-L., Joseph, P., Guillocheau, F., Bourillet, J.-F., Ledrezen, E., and Granjeon, D., 2005. Sedimentary sequences in the Gulf of Lion: A record of 100,000 years climatic cycles: Marine and Petroleum Geology, v. 22, no. 6-7, p. 775-804. 10.1016/j.marpetgeo.2005.03.010:

Rabineau, M., Leroux, E., Aslanian, D., Bache, F., Gorini, C., Moulin, M., Molliex, S., Droz, L., Dos Reis, A. T., Rubino, J. L., Guillocheau, F., and Olivet, J. L., 2014. Quantifying subsidence and isostatic readjustment using sedimentary paleomarkers, example from the Gulf of Lion: Earth and Planetary Science Letters, v. 388, p. 353-366.

Railsback, L. B., Gibbard, P. L., Head, M. J., Voarintsoa, N. R. G., and Toucanne, S., 2015. An optimized scheme of lettered marine isotopique substages for the last 1.0 million years, and the climatostratigraphic nature of isotopic stages and substages: Quaternary Science Reviews, v. 111, p. 94-106.

Rasmussen, E. S., 1994. The relationship between submarine canyon fill and sea-level change: an example from the Middle Miocene offshore Gabon West Africa: Sedimentary Geology, v. 90, p. 61-75.

Rasmussen, E. S., 1997. Depositional evolution and sequence stratigraphy of the shelf and slope area off South Gabon, West Africa: Journal of Sedimentary Research, v. 67, no. 4, p. 715-724.

Riboulot, V., Thomas, Y., Berné, S., Jouet, G., and Cattaneo, A., 2014. Control of Quaternary sea-level changes: Geophysical Reasearch Letters, v. 41, no. 14, p. 4970-4977.

Ridente, D., Foglini, F., Minisini, D., Trincardi, F., and Verdicchio, G., 2007. Shelf-edge erosion, sediment failure and inception of Bari canyon on the southwestern Adriatic margin (central Mediterranean): Marine Geology, v. 246, p. 193-207.

Savoye, B., and Piper, D. J., 1991. The Messinian event on the margin of the Mediterranean Sea in the Nice area, southern France: Marine Geology, v. 97, no. 3, p. 279-304.

Shackleton, N. J., 2000. The 100,000-year Ice-age cycle identified and found to lag temperature, carbon dioxide, and orbital eccentricity: Science, v. 289, p. 1897-1902.

Shepard, F. P., 1972. Submarine canyons: Earth-Science Reviews, v. 8, p. 1 -12.

Shepard, F. P., 1981. Submarine canyons: multiple causes and long-time persistence: American Association of Petroleum Geologists Bulletin, no. 65, p. 1062-1077.

Shepard, F. P., and Dill, R. F., 1977. Currents in submarine canyon heads off the north St Croix, U. S. Virgin Islands: Marine Geology, v. 24, p. 39-45.

Siddall, M., Rohling, E. J., Almogi-Labin, A., Hemleben, C., Meischner, D., Schmelzer, I., and Smeed, D. A., 2003. Sealevel fluctuations during th elast glacial cycle: Nature, v. 423, p. 853-858.

Siddall, M., Rohling, E. J., Thompson, W. G., and Waelbroeck, C., 2008. Marine isotope stage 3 sea level fluctuations: data synthesis and new outlook: Reviews of Geophysics, v. 46, no. 4, p. 1-29.

Sierro, F. J., Andersen, N., Bassetti, M. A., Berné, S., Canals, M., Curtis, J. H., Dennielou, B., Flores, J. A., Frigola, J., Gonzalez-Mora, B., Grimalt, J. O., Hodell, D. A., Jouet, G., Pérez-Folgado, M., and Schneider, R., 2009. Phase 
relationship between sea level and abrupt climate change: Quaternary Science Reviews, v. 28, no. 25-26, p. 2867-2881. 10.1016/j.quascirev.2009.07.019:

Stuiver, M., and Reimer, P. J., 1993. Extended 14C database and revised CALIB radiocarbon calibration program: Radiocarbon, v. 35, p. 215-230.

Sultan, N., Voisset, M., Marsset, B., Marsset, T., Cauquil, E., and Colliat, J.-L., 2007. Potential role of compressional structures in generating submarine slope failures in the Niger delta: Marine Geology, v. 237, p. 169-190.

Swift, D. J. P., 1973. Delaware Shelf Valley: estuary retreat path, not drowned river valley: Geological Society of American Bulletin, v. 84, p. 2743-2748.

Swift, D. J. P., and Thorne, J. A., 1991. Sedimentation on continental margins, I: a general model for shelf sedimentation, in Swift, D. J. P., Oertel, G. F., Tillman, R. W., and Thorne, J. A., eds., Shelf sand and sandstone bodies: Geometry, Facies and Sequence Stratigraphy, Volume International Association of Sedimentologists Special Publication 14: Oxford, Blackwell, p. 3-31.

Tesson, M., Labaune, C., Gensous, B., Suc, J.-P., Melinte-Dobrinescu, M., Parize, O., Imbert, P., and Delhaye-Prat, V., 2011. Quaternary "compound" incised valley in a microtidal environment, Roussillon continental shelf, western Gulf of Lions, France: Journal of Sedimentary Research, v. 81, p. 708-729.

Tesson, M., Posamentier, H., and Gensous, B., 2015. Compound incised-valley characterization by high-resolution seismics in a wave-dominated setting: Example of the Aude and Orb rivers, Languedoc inner shelf, Gulf of Lion, France: Marine Geology, v. 367, no. 0, p. 1-21.

Tesson, M., Posamentier, H. W., and Gensous, B., 2000. Stratigraphic organization of Late Pleistocene deposits of the Western part of the Golfe du Lion shelf (Languedoc shelf), Western Mediterranean sea, using highresolution seismic and core data: American Association of Petroleum Geologists Bulletin, v. 84, no. 1, p. $119-150$.

Twichell, D. C., and Roberts, D. G., 1982. Morphology, distribution, and development of submrine canyons on the unites States Atlantic continental slope between Hudson and Baltimore Canyons: Geology, v. 10, p. 408412.

Van Wagoner, J. C., Mitchum, R., Campion, K., and Rahmanian, V., 1990. Siliciclastic sequence stratigraphy in well logs, cores, and outcrops: concepts for high-resolution correlation of time and facies.

Weimer, P., 1989. Sequence stratigraphy of the Mississippi fan (Plio-Pleistocene), Gulf of Mexico: Geo-marine Letters, v. 9, no. 4, p. 185-272.

Wiles, E., Green, A., Watkeys, M., Jokat, W., and Krocker, R., 2013. The evolution of the Tugela canyon and submarine fan: A complex interaction between margin erosion and bottom current sweeping, southwest Indian Ocean, South Africa: Marine and Petroleum Geology, v. 44, p. 60-70.

Yokoyama, Y., Lambeck, K., De Deckker, P., Johnston, P., and Fifield, L. K., 2000. Timing of the Last Glacial Maximum from observed sea-level minima: Nature, v. 406, p. 713-716.

Figure 1: Physiographic map of the Gulf of Lions (contour line spacing is $5 \mathrm{~m}$ on the continental shelf and $50 \mathrm{~m}$ on the slope). Major canyons are represented: Lacaze-Duthiers canyon (LDC), Bourcart canyon (BC), Herault canyon (HC), Sete canyon (SC) and Petit Rhone canyon (PRC). Please note that borehole PRGL1 and core MD99 2348 are at the same location.

Figure 2: Seismic data set used for interpretation in this study and positions of cores/boreholes (blue dots). Red lines represent seismic profiles displayed in this study.

Figure 3: Shaded swath bathymetric map of the study area. A- General map of the study area, B and C- Close-up views of the Bourcart and Herault canyon heads. 1- "Pierres de Sete" beachrocks. 2- Seaward limit of the offshore sands. 3- E-W oriented relict sand ridges. $\mathrm{H} 1$ to $\mathrm{H} 4$ correspond to the four distributaries of the Herault canyon. SVC 1 and 2: Shelf Valley Complexes left by fluvial 
retreat during the Deglacial sea-level rise. In Fig. 3C, the dashed and dotted lines correspond to the retreat path of shelf valley complex 2 . Note that canyons displaying a meandering axial incision (Bourcart and $\mathrm{H} 2-\mathrm{H} 3$ canyons) are all connected to a fluvial system visible on the shelf morphology. See explanations in section 5.1 .

Figure 4: Morphology of the Bourcart canyon head area (A) and curvilinear gradient along the fluvial/axial incision (B). The curvilinear gradient of the axial incision (and of the adjacent continental shelf) can be separated into four distinct domains: a (in gray): on the continental shelf, the average slope is $0.1^{\circ}$; $\mathbf{b}$ (in green): canyon rim; the average slope is $2.1^{\circ}$; $\mathbf{c}$ (in red): meandering axial incision where the average slope is $0.9^{\circ}$ and the sinuosity index about 2 ; $\mathbf{d}$ (in blue): linear axial incision with an average slope of $1.4^{\circ}$. The transition between the meandering and linear axial incision is marked by a gradient increase. Beachrocks formed after fluvial disconnection (see section 5.2.2 for details).

Figure 5: Seismic sparker profiles (A:1040 and B:1020, position in Fig.2) on the west rim of the Bourcart canyon head, across the Western Incised Valley. Note the distinct erosional nature of the present-day sea floor (with toplap terminations) at the position of the ancient river path. Seismic surfaces are defined in section 5.2.1.

Figure 6: Multi-channel seismic dip section (Marion12; location in Fig. 2) along the Bourcart/Herault interfluve. Colored lines are the major seismic surfaces identified in the study area (D67 being an additional timeline without stratigraphic significance). Their ages were determined at the position of borehole PRGL1 (from Sierro et al., 2009) and, to a lesser extent, borehole PRGL2 (from Bassetti et al., 2008) and core MD99-2349 (from Jouet et al., 2007). Conventional ages of these authors have been re-calibrated with Calib 7.0.2 (Stuiver and Reimer, 2013). The sketch illustrates the "r" and "f" ("s" and "m" for the major bounding surfaces linked to $100 \mathrm{kyr}$ glacial/interglacial cycles) surfaces on the shelf and on the slope (further details in section 5.2.1).

Figure 7: Time constraints of seismic surfaces from hole PRGL1. A: Multi-channel (Stack20R) and B Chirp seismic profile (Calim167) at the position of the borehole. Oxygen isotope ratios, sand 
fraction $(>63 \mu \mathrm{m})$ and $\mathrm{Ti} / \mathrm{Ca}$ ratio are given at the position of the borehole. Depth is given thanks to the reconstruction of the P-wave velocity and then its conversion from millisecond two-way travel time to meters below seafloor. P-wave velocities from PRGL 1 were altered by strong sediment degassing. The climatic events corresponding to the variations in those parameters are highlighted in red for the warmer events and blue for the cold ones. High sand fractions correspond to condensed intervals during interglacials (MIS1 and MIS5.e) and to the most pronounced interstadials (IS16, 14 or 8). They correspond well with low $\delta 018$ values (warmer periods). All seismic surfaces are drawn on both seismic profiles. Note the presence of high amplitude reflections between D60m and D63f (especially on profile A). They correspond to Interstadials 16, 12 and 14.

Figure 8: Correspondence between seismic surfaces described in this study, sea-level and climatic events during the last 150 kyr. The composite sea-level curve is based on Grant et al., 2012 (red; from 150 to $\approx 60 \mathrm{kyr}$ ), Arz et al., 2007 (black; from $\approx 60$ to $\approx 20 \mathrm{kyr}$ ) and Lambeck et al., 2014 (green; for the last $\approx 20 \mathrm{kyr}$ ) in order to better represent the variability of high-frequency sea-level changes and their link with seismic surfaces. A: Composite sea-level curve with climatic event terminologies according to Railsback et al., 2015 (for MIS and Terminations) and to Sierro et al., 2009 (for Heinrich stadials (HS) and Interstadials (IS)). In addition, sequence boundaries (D60s and D70s) and the maximum flooding surface $(\mathrm{D} 60 \mathrm{~m})$ are presented. B: Focus on the last $50 \mathrm{kyr}$ with the regressive erosion surfaces corresponding to Heinrich stadials (low sea-level) and the flooding surfaces in phase with the following Interstadial (higher sea-level). The gray rectangle highlights the period of beachrock cementation.

Figure 9: Seismic facies in the Bourcart canyon infill (position in Fig. 2). A: Channel-levee system with (1) parallel or sigmoid, medium to high-amplitude, continuous reflections interpreted as turbidites along the levees and (2) high-amplitude, chaotic reflections within the channel (HARs) (line Stch80) B: HARs within the meanders of the axial incision (line 1021); C: Mass transport deposits (MTDs (3)) incased within turbidite/hemipelagite. Note the erosional nature of the lower bounding surface (line 5078). 
Figure 10: Uninterpreted and interpreted seismic profile (sparker line 5080, position Fig. 11) across the Bourcart canyon fill. Seismic surfaces have been propagated from borehole PRGL1. Three mass transport deposits (MTD1, 2 and 3) can be recognized. MTD2 and MTD3 have been mapped (Fig. 11).

Figure 11: Position of the two main MTDs (MTD2 and MTD3) in the Bourcart Canyon Head. A-A' represents the position of seismic line in Figure 10.

Figure 12: Channelized systems topped by a lateral accretion/aggradation seismic facies A: Confined channel-levee system with aggradation/lateral accretion in green, levees in red and chaotic facies in dark coloring (Line 1022). B: Profile and its line drawing crossing the beachrocks and displaying three channels and their aggradation/lateral accretion seismic facies (line STACK13R, position in Fig. 2).

Figure 13: A: Localization of the buried channels on a profile (sparker profile 5072) perpendicular to the canyon head and $\mathbf{B}$ : its line drawing. Note that the surfaces on both rims of the canyon are " $r$ " (erosion surfaces from the interfluve) but merged with " $\mathrm{f}$ " in the infill of the canyon (flooding surface; section 5.2.1 for more details). C: Close-up view of the initiation of sigmoidal channel-levees around 37 cal ka BP (surface D63f). The dark shade shows the chaotic facies. Note, within the buried channels the transition between HAR and fluvial/estuarine seismic facies above roughly corresponds to the time of formation of the sequence boundary (D70s), i.e. $21.5 \mathrm{cal}$ ka BP. For group description refer to the section 5.3. The position of D70s in the Bourcart canyon head is not precisely known.

Figure 14: Evolution of the fluvial connections with the Bourcart canyon head. The time frames mentioned for each group correspond to the broadest time spans on the basis of possible stratigraphic correlations. Regarding group 1, an early connection around $39 \mathrm{ka}$ is possible, but more evidence for direct connection is observed after ca $27 \mathrm{ka}$. Red lines are the active fluvial systems while the gray lines represent the inactive/buried fluvial systems. Note that the $-160 \mathrm{~m}$ contour line is thicker in order to highlight the canyon incision. 
Figure 15: Isopach maps of the three major seismic units infilling the Bourcart canyon head during the last glacial/interglacial cycle. The time spans corresponding to the boundaries of these seismic units are represented, together with their duration in kyr. 17 ka corresponds to the "age of the seafloor"', considering that sedimentation stopped around this time in the canyon head. Note that the ages of seismic surfaces were determined from correlation with core data and may slightly vary laterally.

Figure 16: "Progradation" of the Bourcart canyon head during the last glacial cycle. This map represents the position of the "200 m contour line" (with respect to present sea-level) at various stages of the last glacial cycle. An average subsidence rate of $250 \mathrm{~m} / \mathrm{Myr}$ (Rabineau et al., 2014) was applied to correct the position of the contour lines.

Figure 17: Synthetic summary of the last ca. 100 kyr Bourcart canyon infill, and its relation with shelf-edge sequences (not at scale). The scenario is described in the text (section 5.4.1). The sealevel curve is simplified from figure $8 \mathrm{~B}$.

Table 1: Summary of the main characteristics of seismic surfaces used in this study. Their seismic characteristics, depth on PRGL1, ages and corresponding climato-eustatic events are given. Ages at the position of cores and boreholes are first given in conventional $14 \mathrm{C}$ age from the age model of Sierro et al. (2009) on PRGL1 and MD99-2348. The calibrated ages have then been updated with CALIB 7.0.2 software corrected for an air-sea reservoir effect of 400 years (Stuiver and Reimer, 1993). Ages older than ca. 40 cal ka BP are determined by correlations between proxies of hole PRGL1 and the NGRIP and SPECMAP data (Sierro et al., 2009).

Table 2: Characteristics of both beachrock samples. The lower sample (sample 2) corresponds to the onset of cementation starting at about $19 \mathrm{cal}$ ka BP. The upper sample marks out the end of cementation at almost 18 cal ka BP. The calibrated ages of the cemented beachrock samples have been updated thanks to CALIB 7.0.2 software corrected for an air-sea reservoir effect of 400 years (Stuiver and Reimer, 1993). 


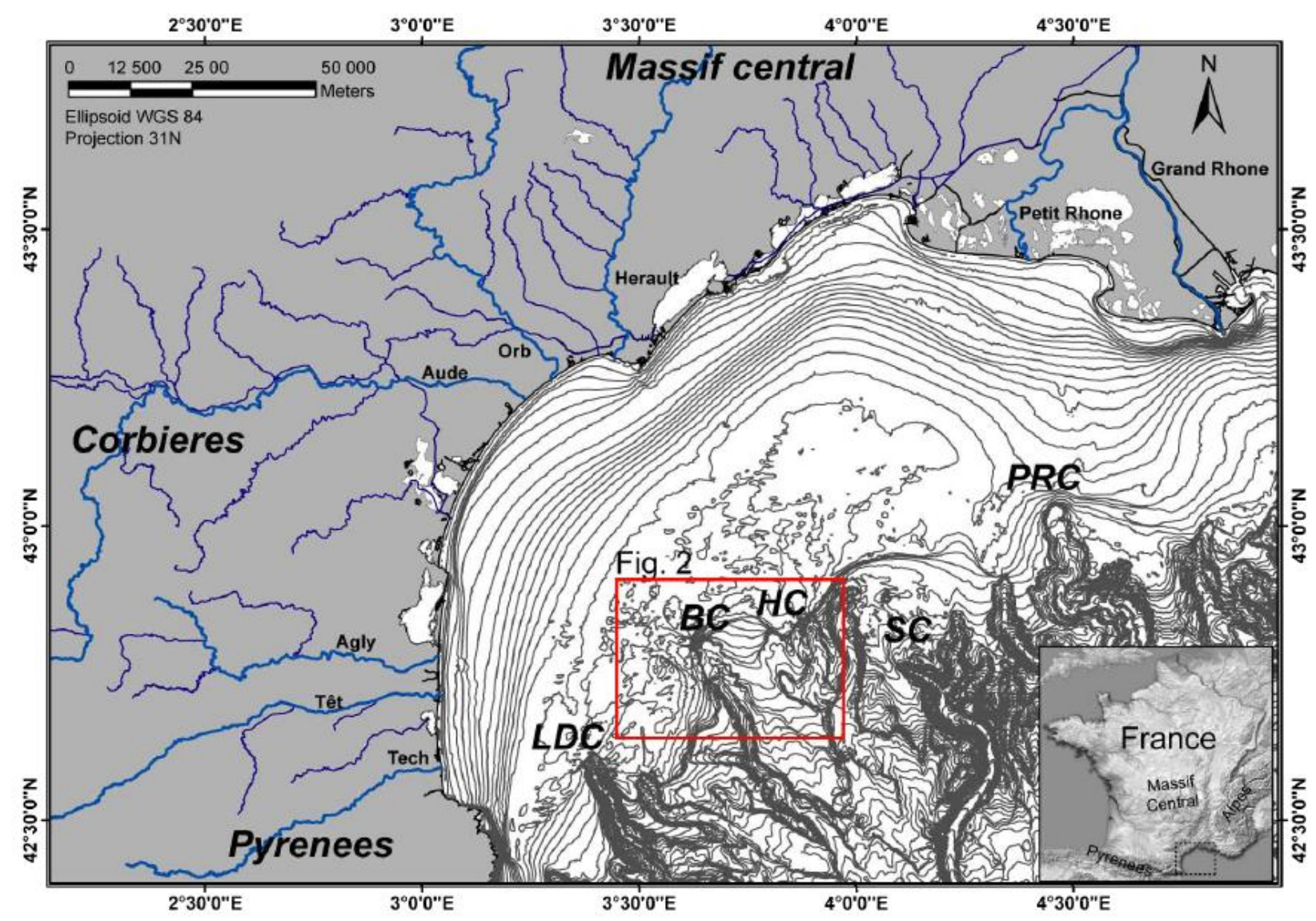

Figure 1 


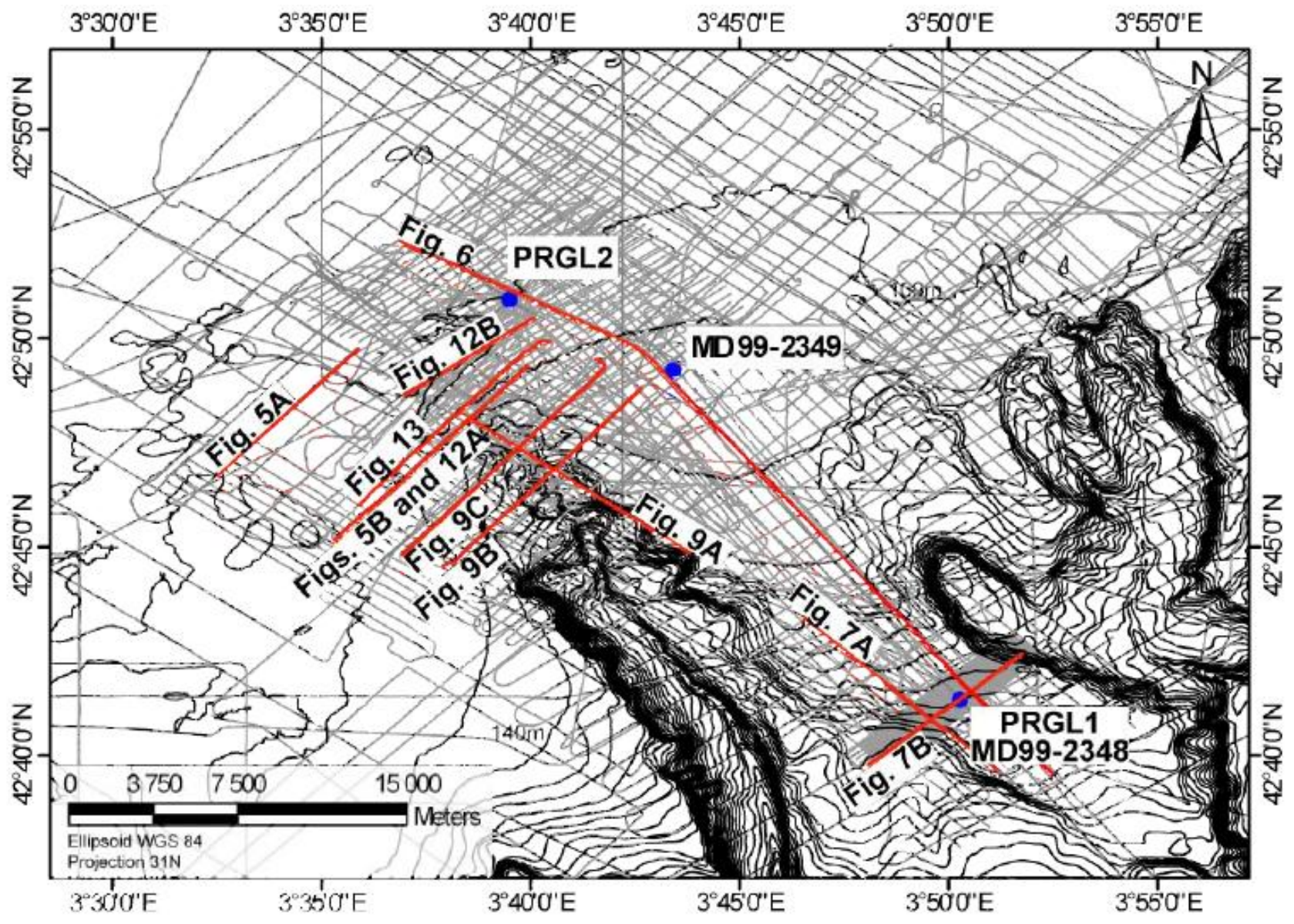

Figure 2 
ACCEPTED MANUSCRIPT
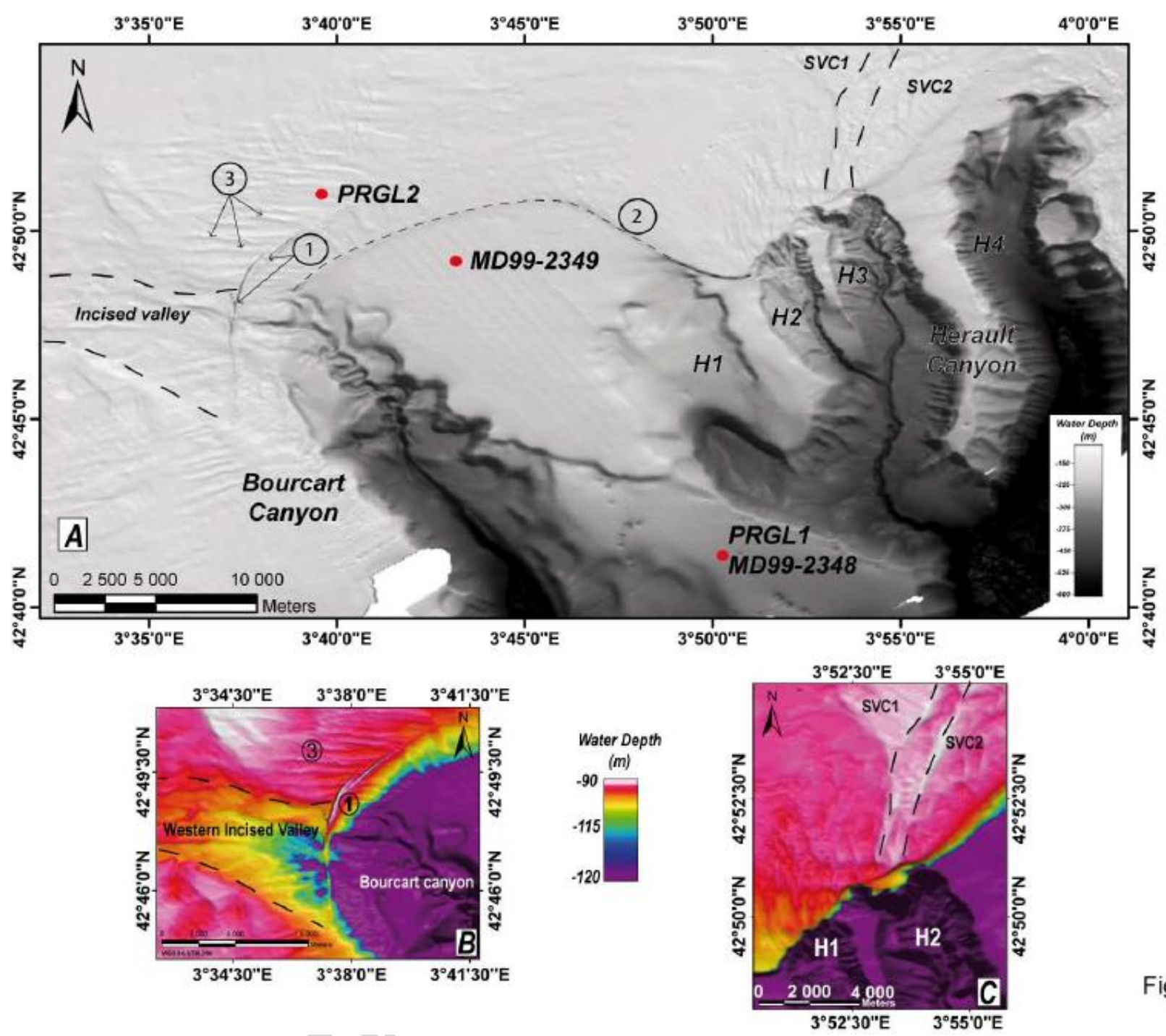

Figure 3 


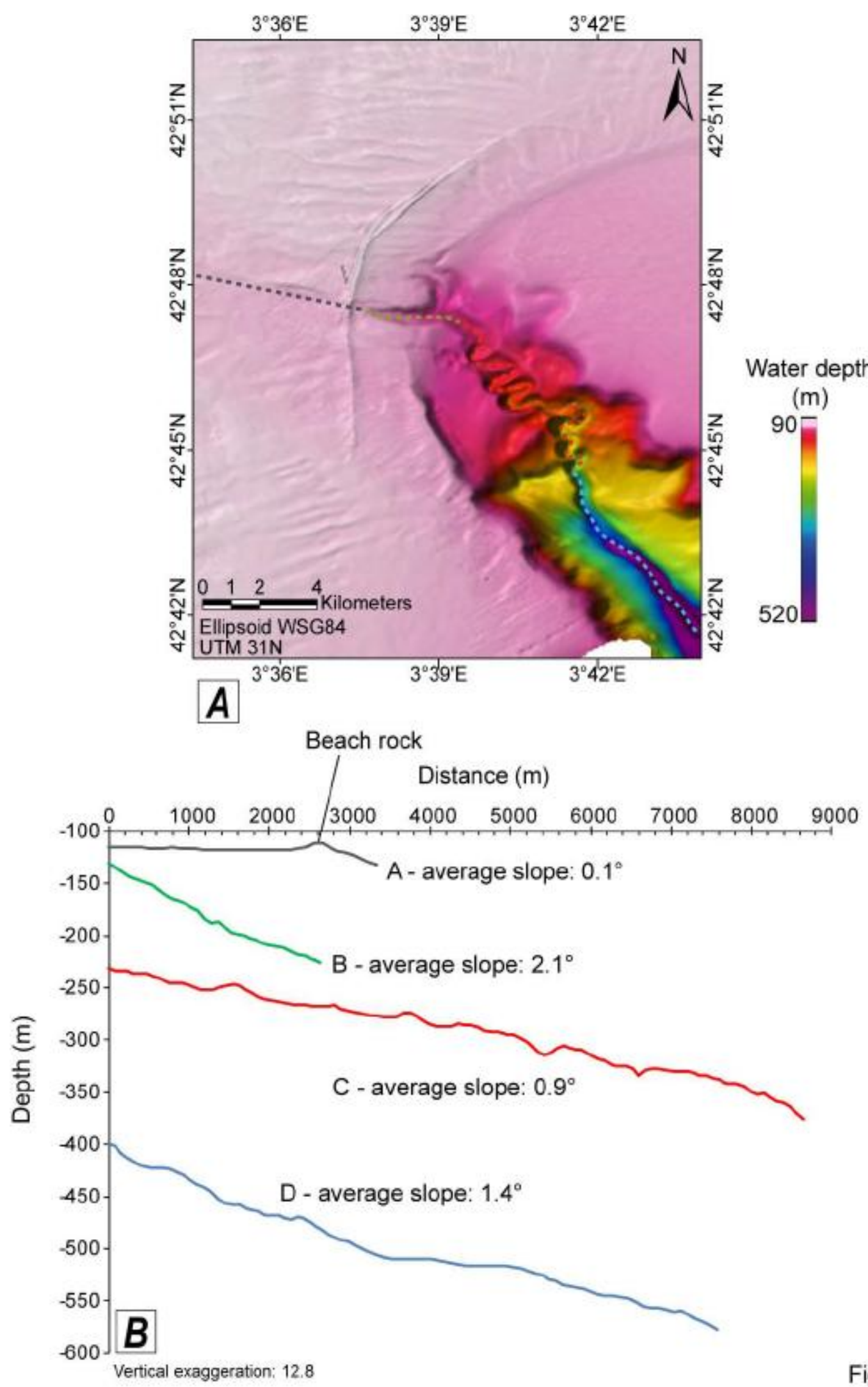

Figure 4 


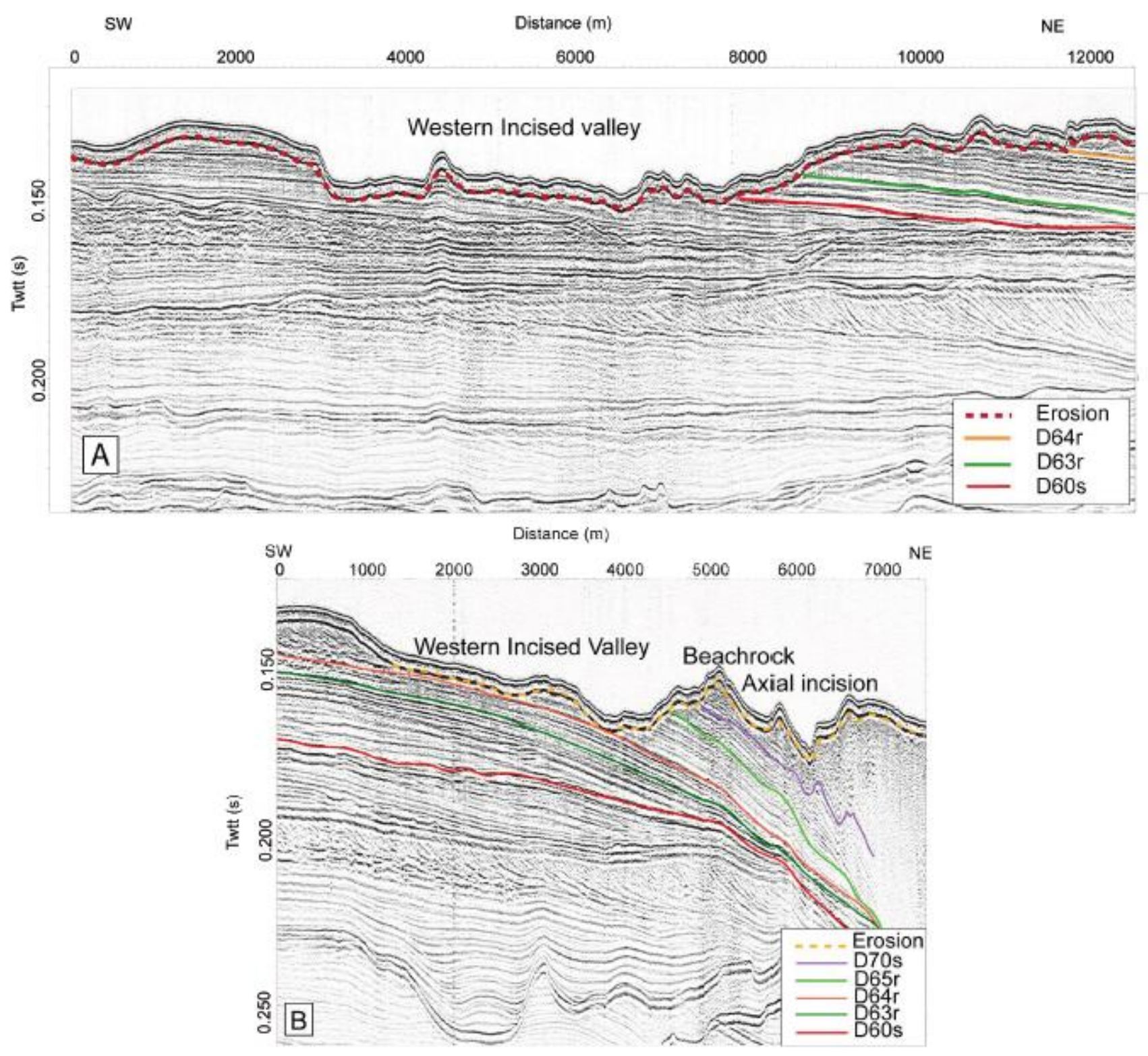

Figure 5 


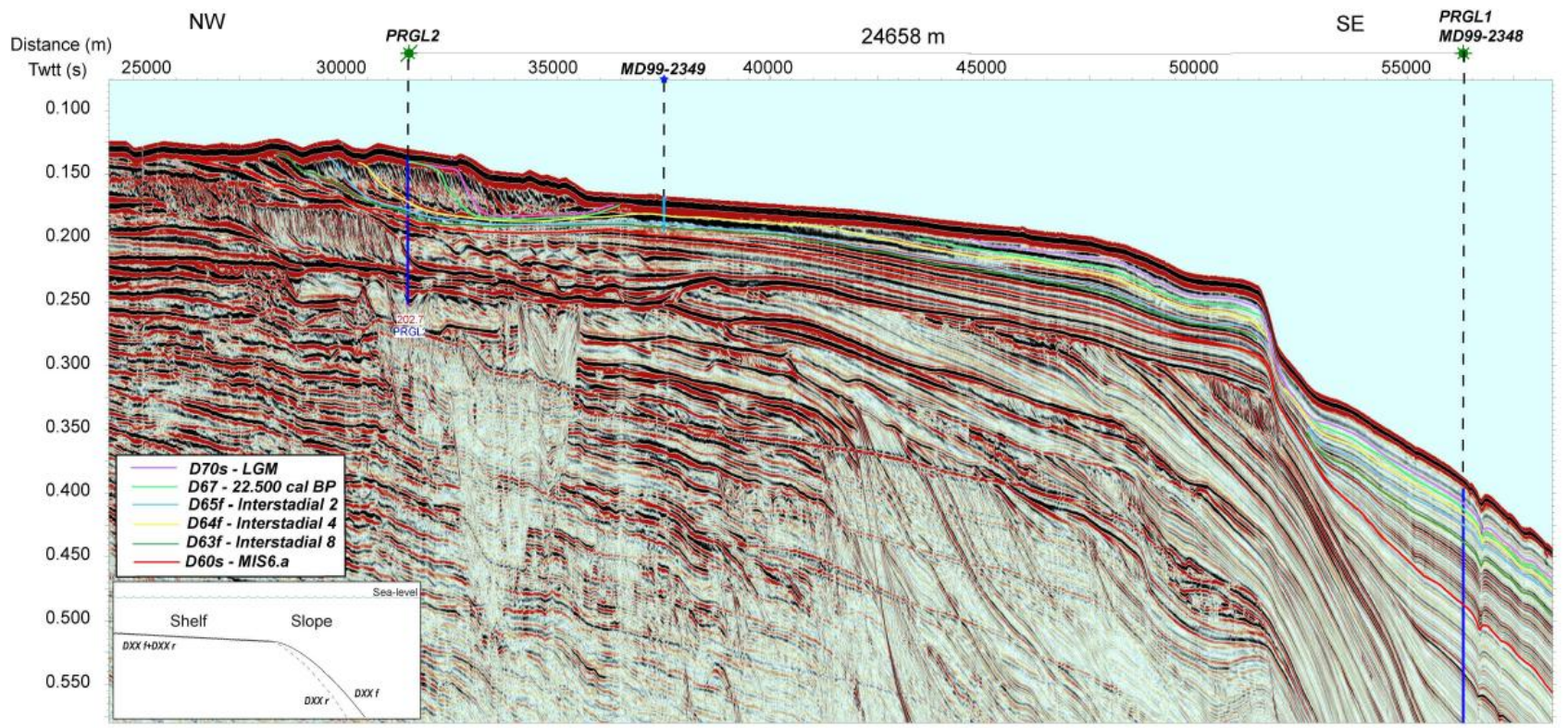

Figure 6 


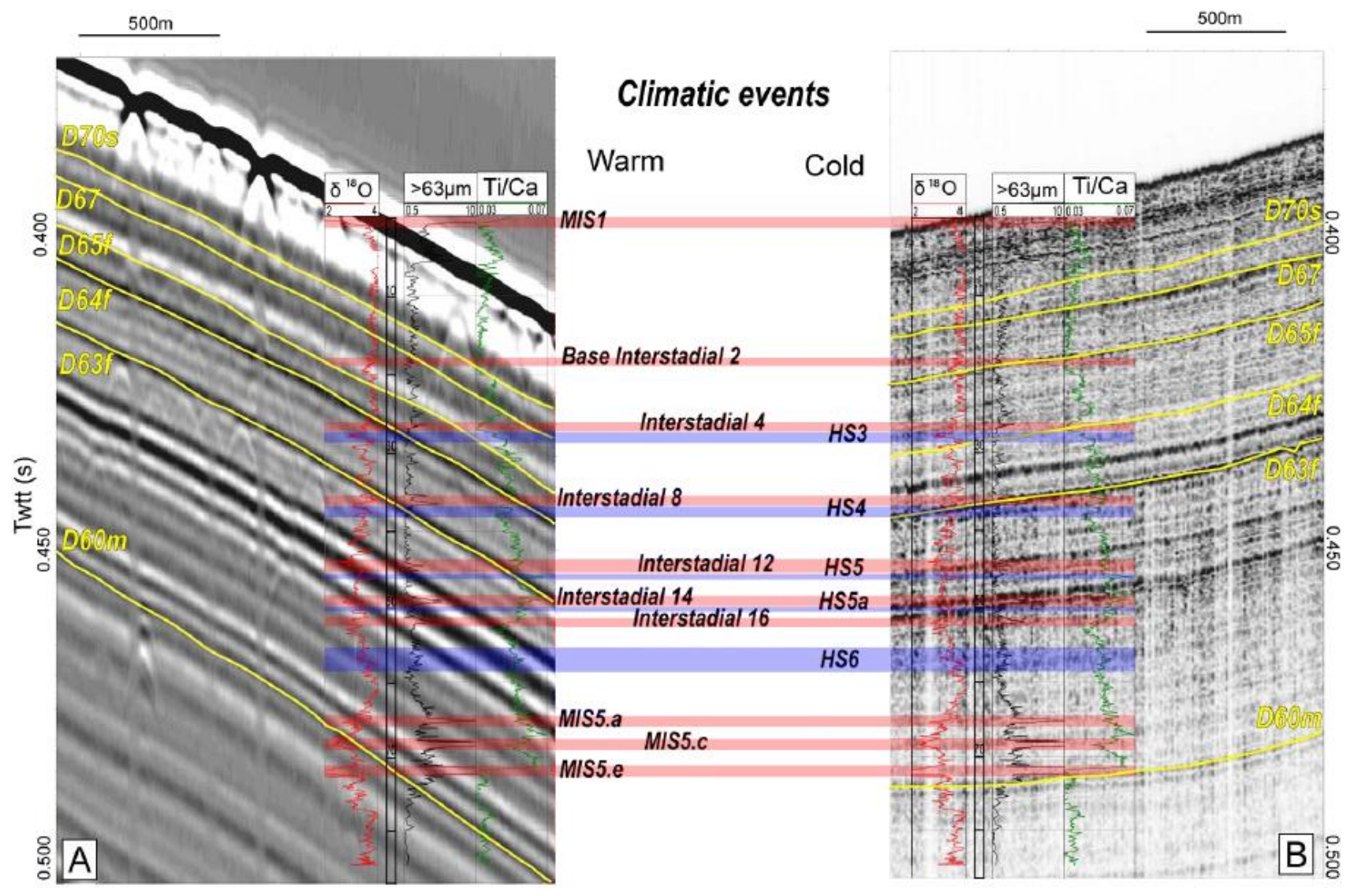

Figure 7 

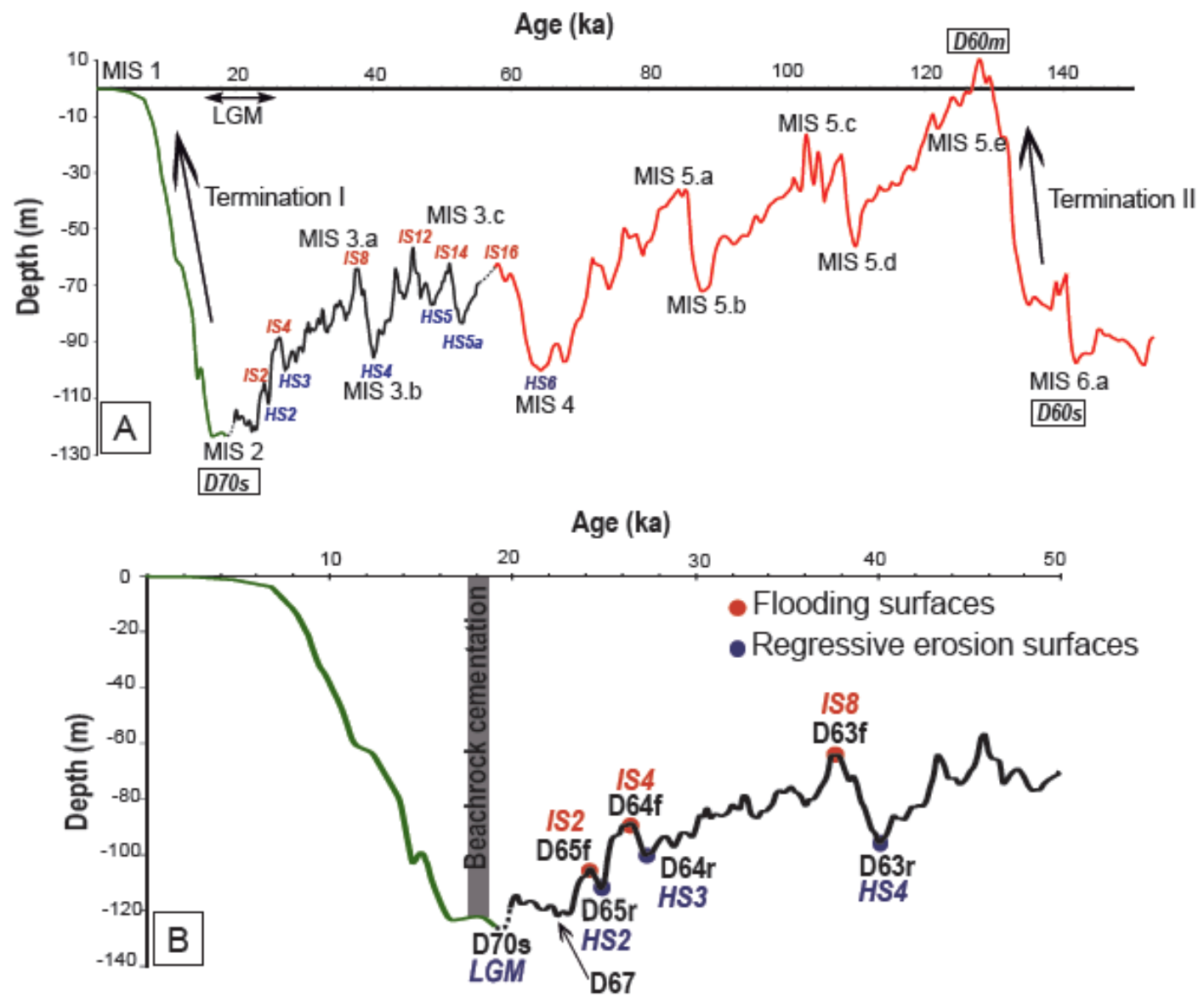

Figure 8 

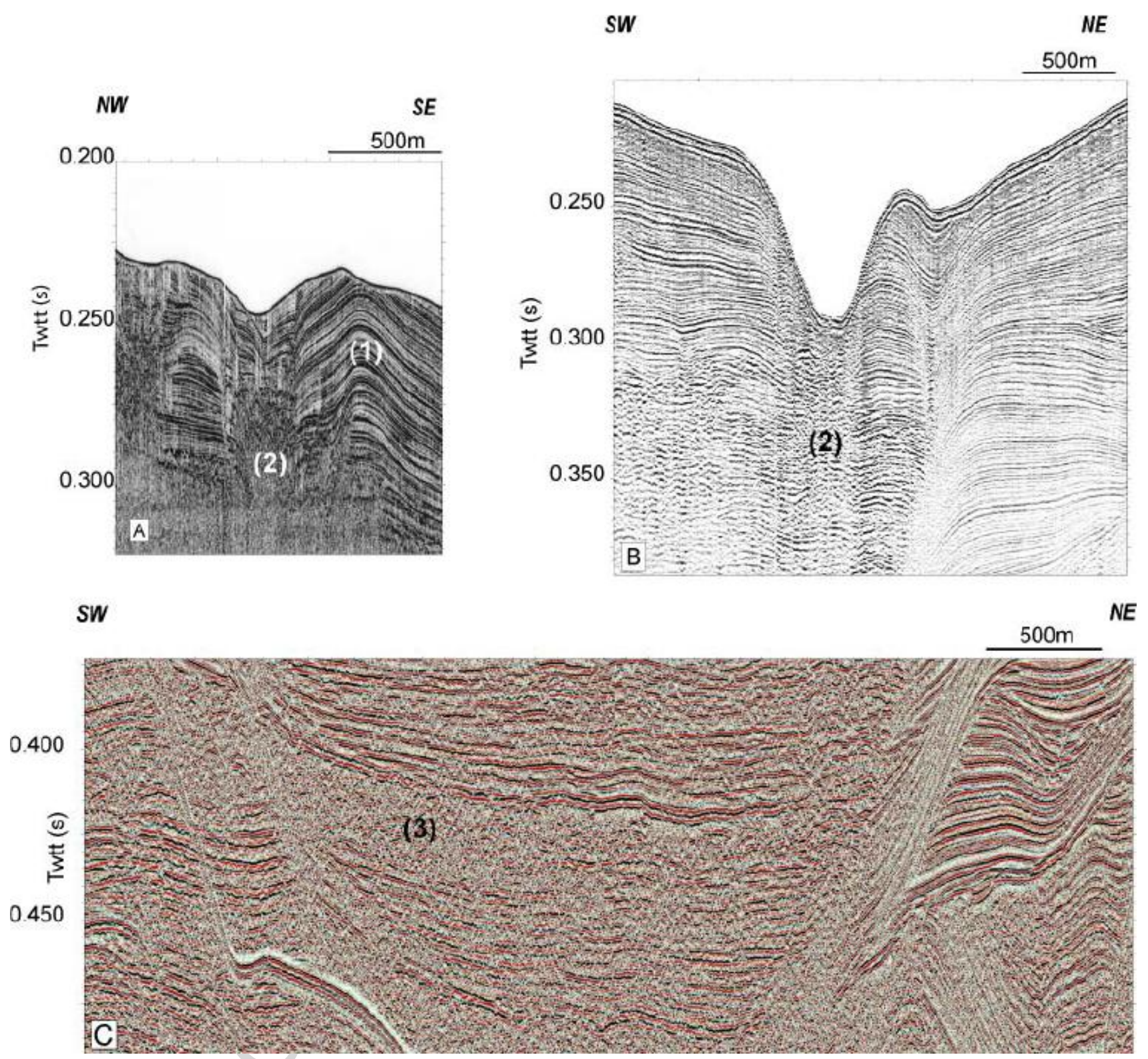

Figure 9 


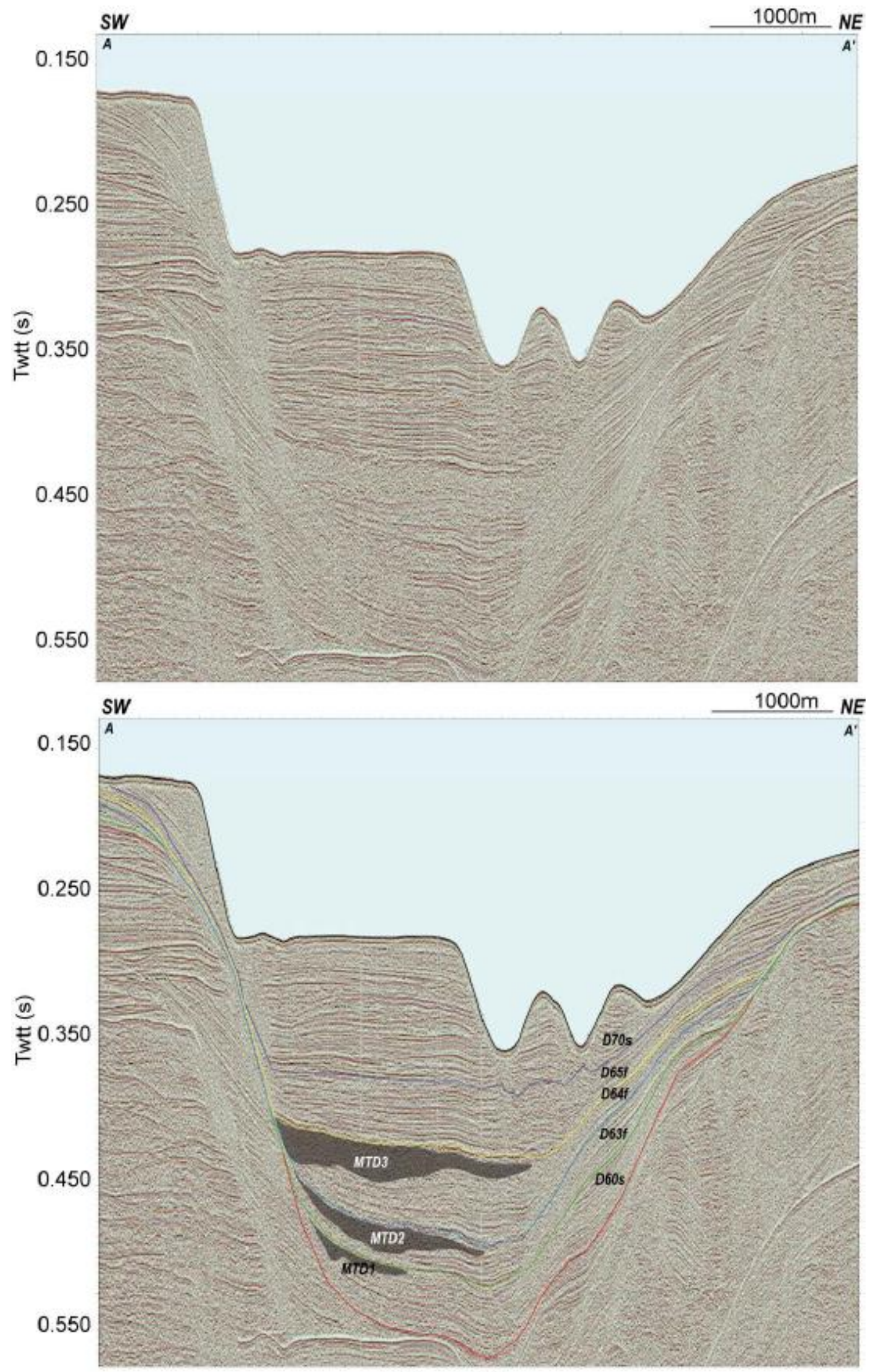

Figure 10 


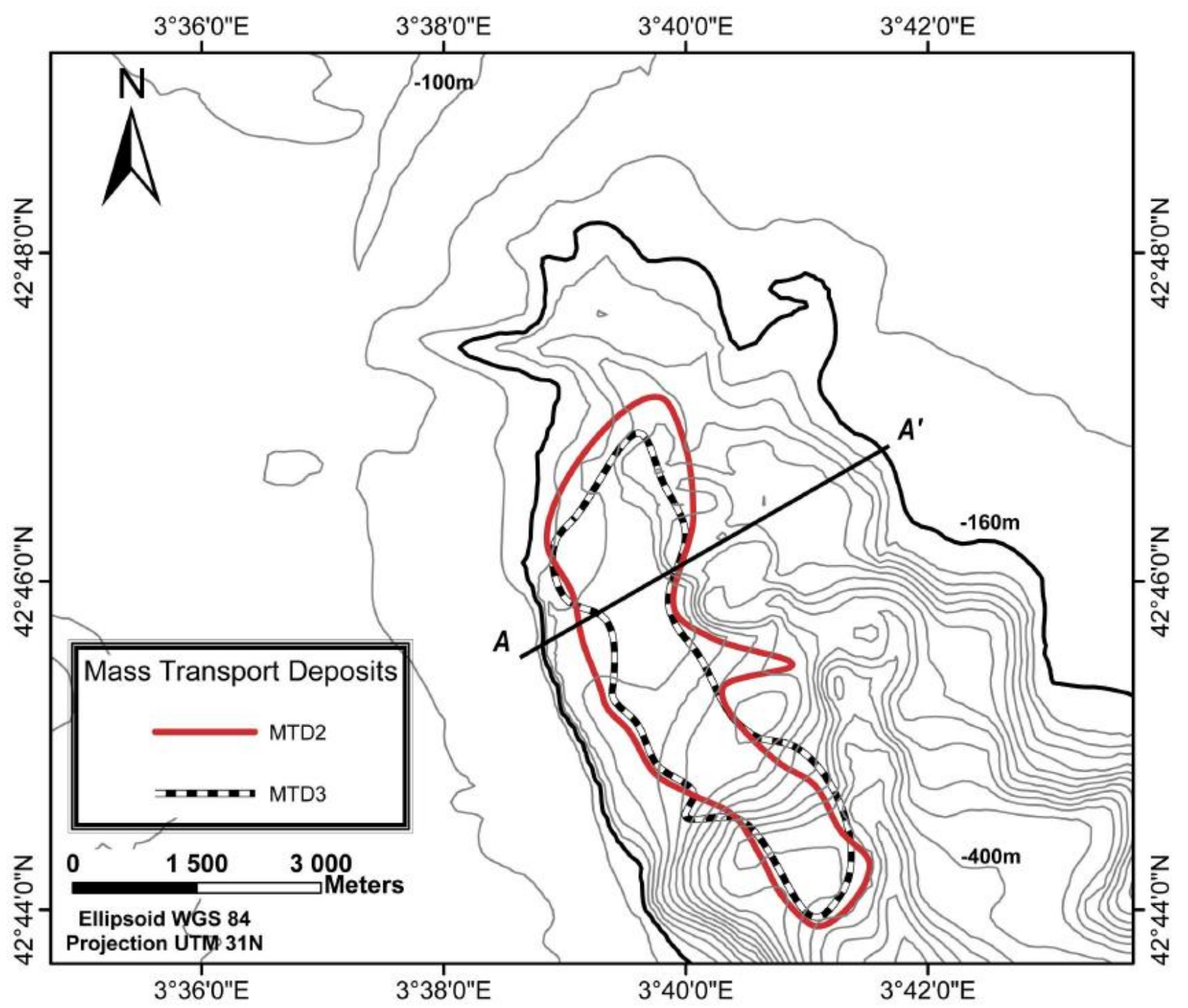

Figure 11 

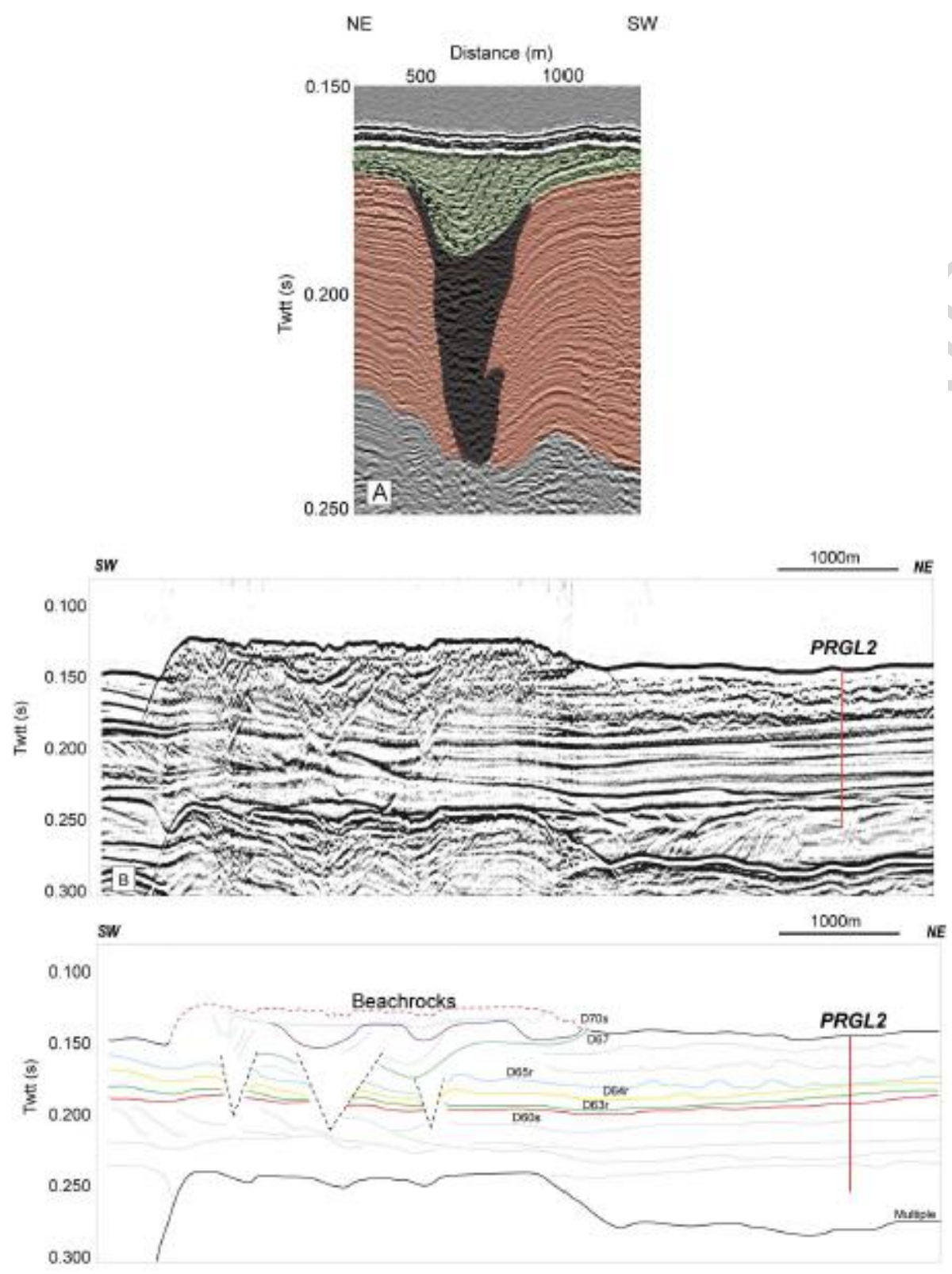

Figure 12 


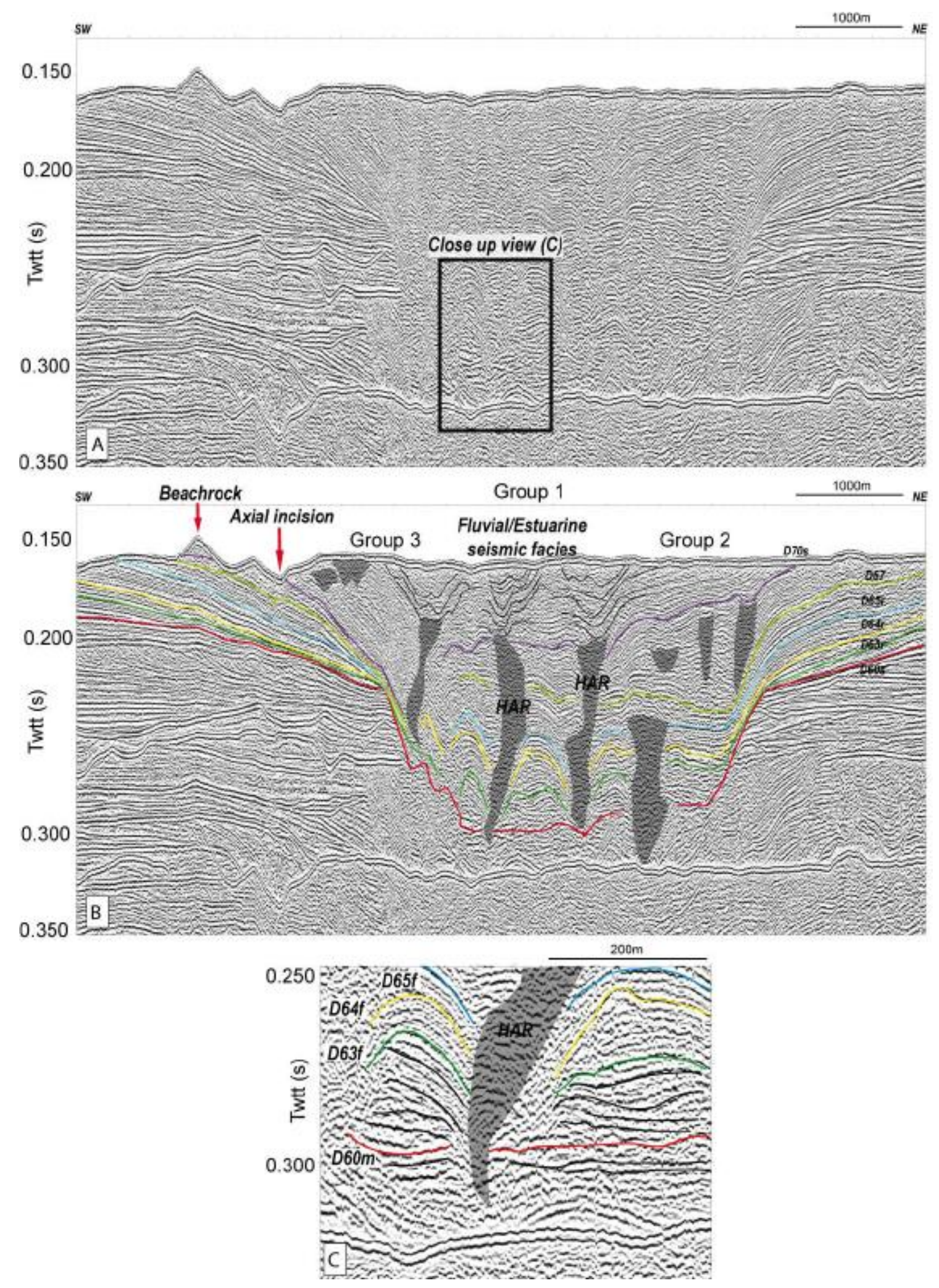

Figure 13 

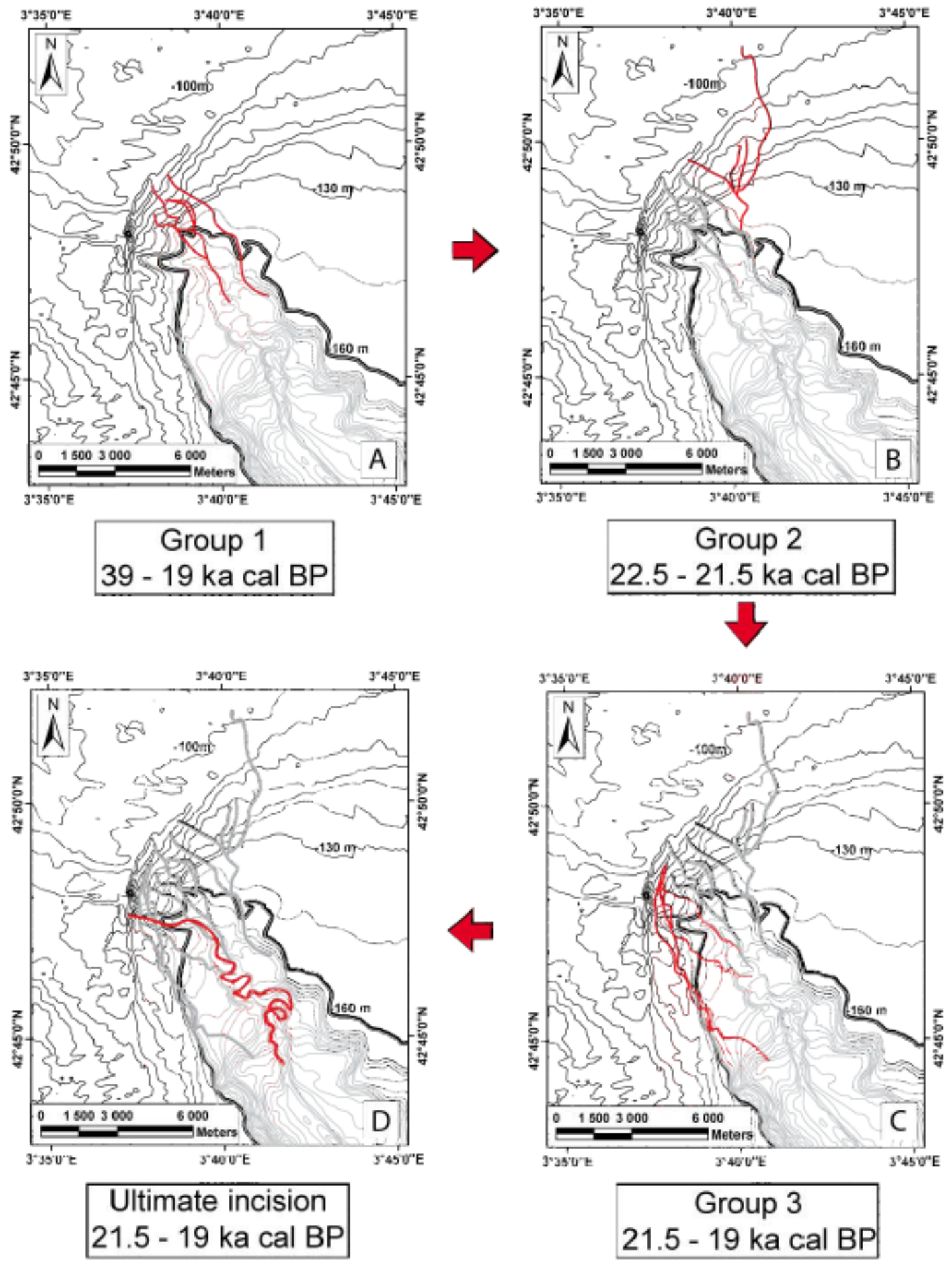

\section{Figure 14}


$\mathrm{X} / \mathrm{Y}$ :
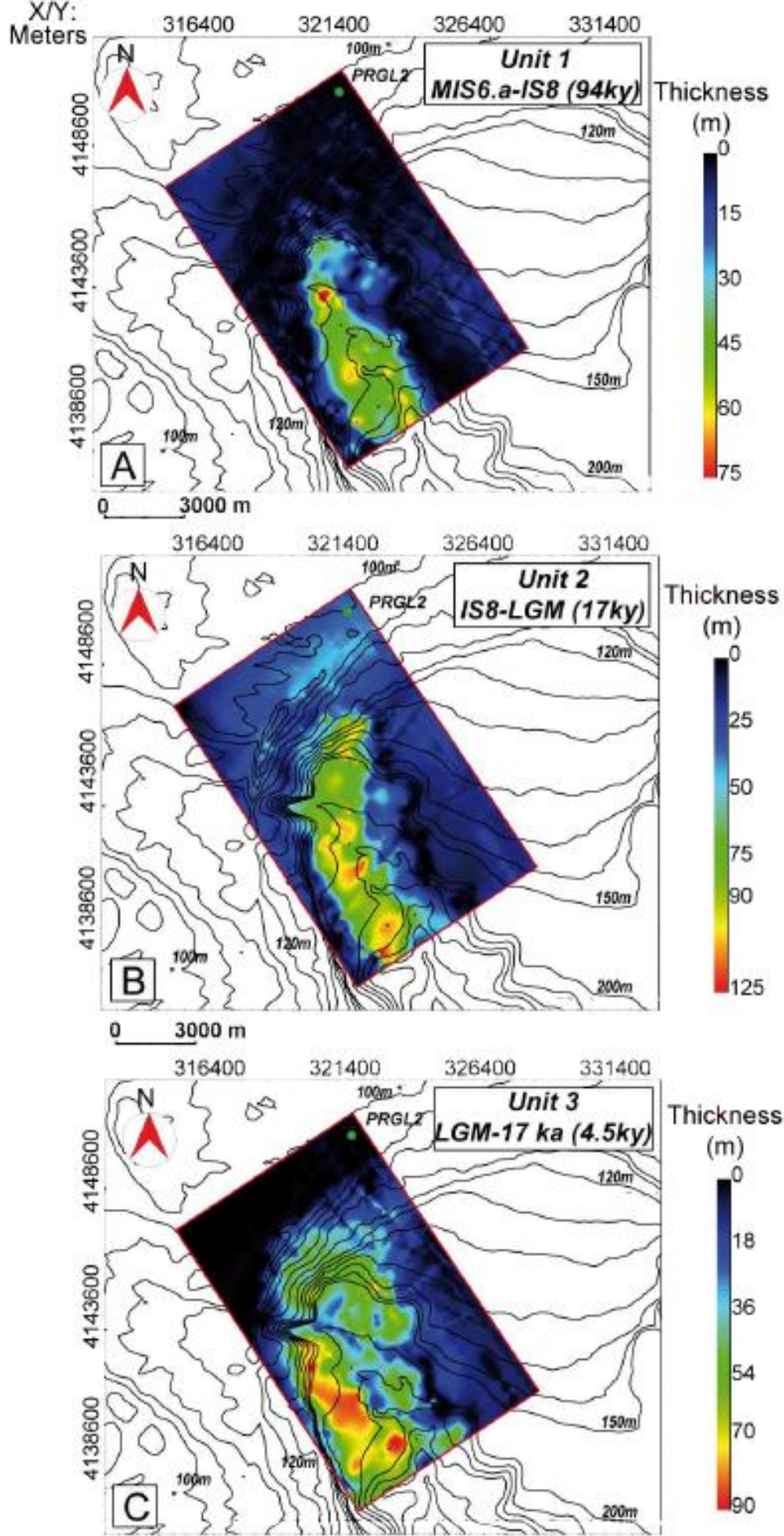

0 $3000 \mathrm{~m}$ 


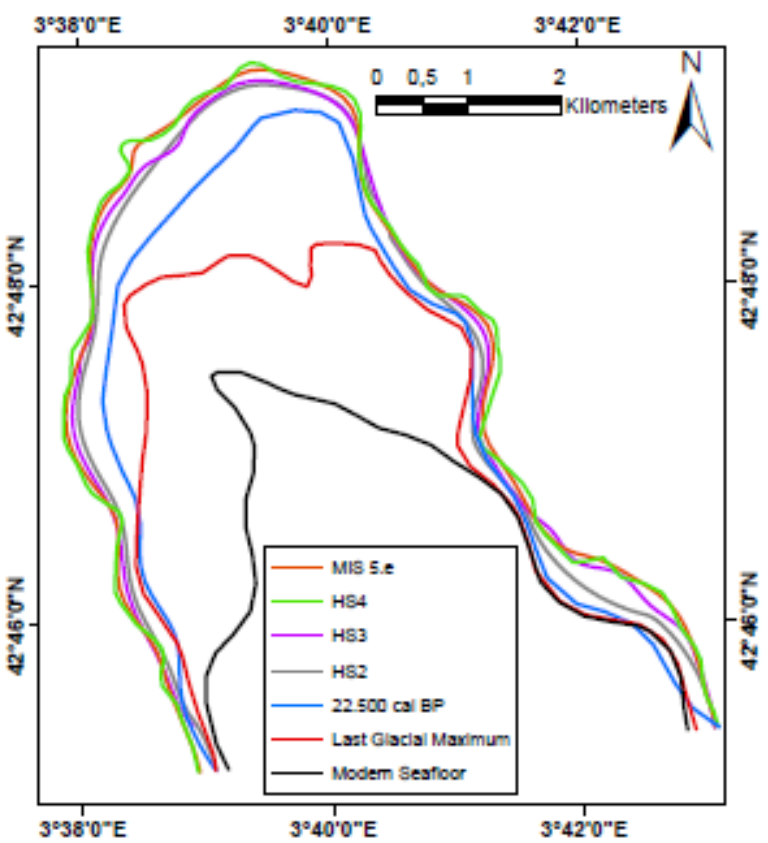

Figure 16 


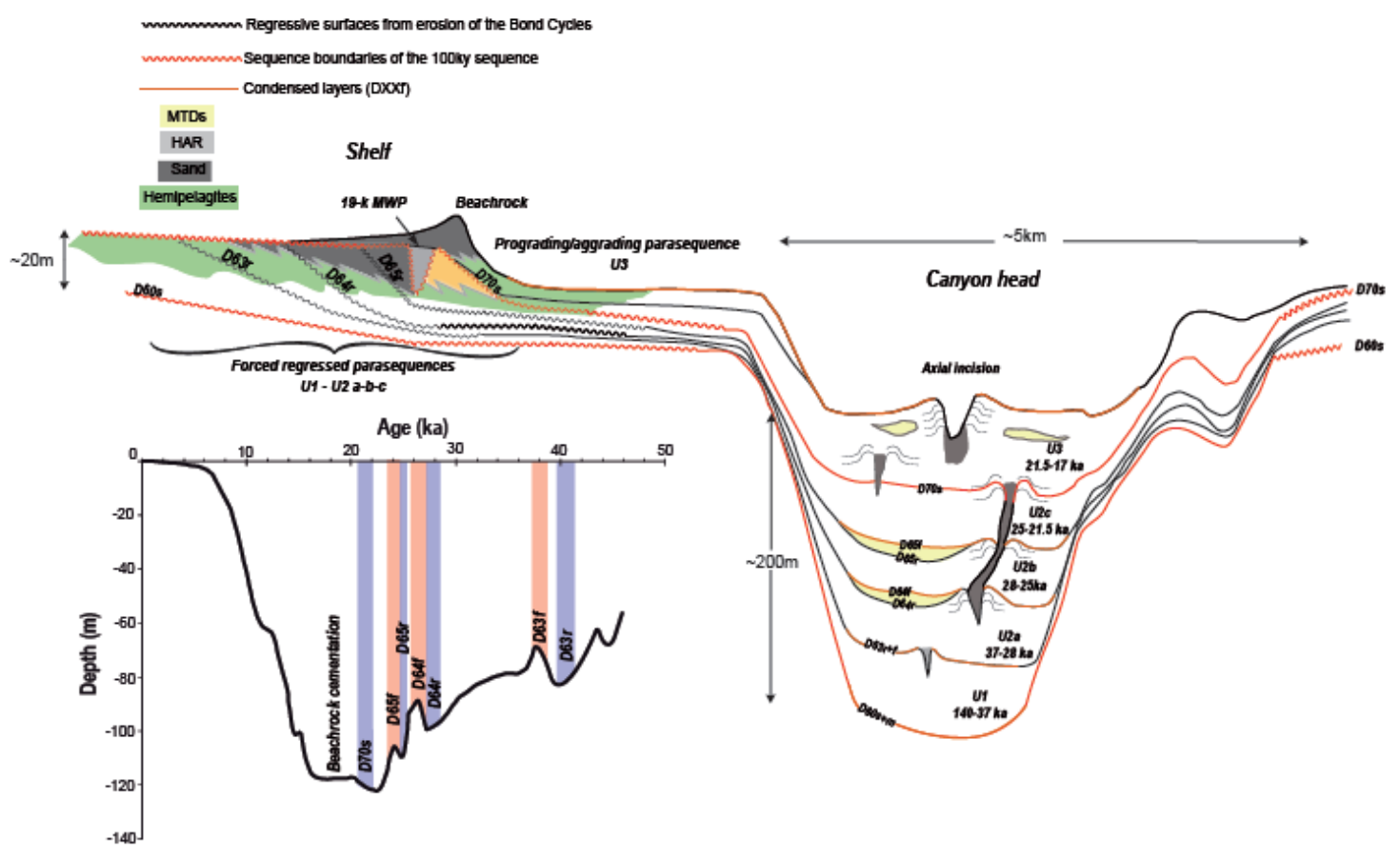


Table 1

\begin{tabular}{|c|c|c|c|c|c|c|c|c|c|}
\hline Surfaces & $\begin{array}{c}\text { Characteristics } \\
\text { on shelf }\end{array}$ & $\begin{array}{l}\text { Characteristics on } \\
\text { canyon head }\end{array}$ & $\begin{array}{l}\text { Characteristics } \\
\text { on interfluve } \\
\text { (PRGL1) }\end{array}$ & $\begin{array}{c}\text { Depth } \\
\text { at the } \\
\text { position } \\
\text { on } \\
\text { PRGL } \\
1 \\
\text { (mbsf) }\end{array}$ & $\begin{array}{c}\text { Conventional } \\
14 \mathrm{C} \text { age (yr } \\
\text { BP; from } \\
\text { Sierro et al., } \\
\text { 2009) }\end{array}$ & $\begin{array}{l}\text { Calibrated } \\
\text { age (yr } \\
\text { BP) }\end{array}$ & $\begin{array}{l}\text { Corresponding } \\
\text { climato- } \\
\text { eustatic } \\
\text { events }\end{array}$ & \multicolumn{2}{|c|}{$\begin{array}{l}\text { Seismic } \\
\text { units }\end{array}$} \\
\hline Seafloor/D70m & $\begin{array}{c}\text { High- } \\
\text { amplitude, } \\
\text { conformable }\end{array}$ & $\begin{array}{l}\text { High-amplitude, } \\
\text { conformable }\end{array}$ & $\begin{array}{c}\text { High- } \\
\text { amplitude, } \\
\text { conformable }\end{array}$ & 0 & & $\begin{array}{l}\text { About } \\
17,000 \\
\text { cal BP }\end{array}$ & MIS1 & \multirow{2}{*}{\multicolumn{2}{|c|}{ Unit 3}} \\
\hline D70s & $\begin{array}{c}\text { High } \\
\text { amplitude, } \\
\text { unconformity }\end{array}$ & $\begin{array}{l}\text { High to moderate } \\
\text { amplitude }\end{array}$ & Low amplitude & 12.5 & $18,150 \pm 50$ & $\begin{array}{l}21,486.5 \\
\pm 111.5\end{array}$ & LGM & & \\
\hline$D 67$ & $\begin{array}{c}\text { High } \\
\text { amplitude }\end{array}$ & Difficult to track & $\begin{array}{l}\text { Very low } \\
\text { amplitude }\end{array}$ & & & $\begin{array}{c}22,534 \pm \\
93\end{array}$ & - & \multirow[b]{2}{*}{$U 2 c$} & \multirow{6}{*}{$\begin{array}{l}\text { Unit } \\
2\end{array}$} \\
\hline$D 65 f$ & $\begin{array}{c}\text { Merged with } \\
\text { erosion } \\
\text { surface }(\boldsymbol{D} 65 r)\end{array}$ & $\begin{array}{l}\text { High-amplitude, } \\
\text { conformable, } \\
\text { immediately above } \\
\text { MTD3 }\end{array}$ & $\begin{array}{l}\text { High- } \\
\text { amplitude, } \\
\text { conformable }\end{array}$ & 19 & $20,900 \pm 100$ & $\begin{array}{c}24,667 \pm \\
198\end{array}$ & Interstadial 2 & & \\
\hline$D 65 r$ & $\begin{array}{c}\text { High- } \\
\text { amplitude, } \\
\text { toplap } \\
\text { terminations }\end{array}$ & Merged with D65f & Low amplitude & & & $\approx 25,000$ & $\begin{array}{l}\text { Heinrich } \\
\text { Stadial } 2 \\
\text { (HS2) }\end{array}$ & \multirow[b]{2}{*}{$U 2 b$} & \\
\hline$D 64 f$ & $\begin{array}{c}\text { Merged with } \\
\text { erosion } \\
\text { surface }(D 64 r)\end{array}$ & $\begin{array}{l}\text { High-amplitude, } \\
\text { conformable, } \\
\text { immediately above } \\
\text { MTD2 }\end{array}$ & $\begin{array}{l}\text { High- } \\
\text { amplitude, } \\
\text { conformable }\end{array}$ & 27 & $24,100 \pm 100$ & $\begin{array}{l}27,775 \pm \\
90\end{array}$ & Interstadial 4 & & \\
\hline$D 64 r$ & $\begin{array}{l}\text { High- } \\
\text { amplitude, } \\
\text { toplap } \\
\text { terminations }\end{array}$ & $\begin{array}{l}\text { Clear erosion } \\
\text { surface in the } \\
\text { upper canyon } \\
\text { head, merged with } \\
\text { D64f downdip }\end{array}$ & Low amplitude & & & $\approx 28,000$ & HS3 & \multirow{2}{*}{ U2a } & \\
\hline$D 63 f$ & $\begin{array}{l}\text { Merged with } \\
\text { erosion } \\
\text { surface }(D 63 r)\end{array}$ & $\begin{array}{l}\text { High-amplitude, } \\
\text { conformable }\end{array}$ & $\begin{array}{c}\text { High- } \\
\text { amplitude, } \\
\text { conformable }\end{array}$ & 36.5 & $33,350 \pm 400$ & $\begin{array}{l}37,037 \pm \\
600\end{array}$ & Interstadial 8 & & \\
\hline$D 63 r$ & $\begin{array}{l}\text { High- } \\
\text { amplitude, } \\
\text { toplap } \\
\text { terminations }\end{array}$ & Merged with D63f & Low amplitude & & & $\approx 40,000$ & HS4 & \multirow{3}{*}{\multicolumn{2}{|c|}{ Unit 1}} \\
\hline$D 60 m$ & $\begin{array}{c}\text { Merged with } \\
\text { erosion } \\
\text { surface }(D 60 s) \\
\text { Hiah- }\end{array}$ & $\begin{array}{l}\text { High-amplitude, } \\
\text { conformable }\end{array}$ & $\begin{array}{c}\text { High- } \\
\text { amplitude, } \\
\text { conformable }\end{array}$ & 71.5 & & $\approx 131,000$ & MIS 5.e & & \\
\hline D60s & $\begin{array}{l}\text { amplitude, } \\
\text { toplap } \\
\text { terminations }\end{array}$ & Merged with D60m & Low amplitude & 73 & & $\approx 140,000$ & MIS 6.a & & \\
\hline
\end{tabular}


Table 2

\begin{tabular}{|c|c|c|c|c|c|}
\hline & & $\begin{array}{c}\text { Characteristic } \\
\text { on shelf }\end{array}$ & Lab no. & $\begin{array}{c}\text { Conventional } \\
14 \mathrm{C} \text { age (a } \\
\text { BP) }\end{array}$ & $\begin{array}{c}1 \text { sigma Calibrated } \\
\text { age (a BP; from } \\
\text { Calib 7.0.2) }\end{array}$ \\
\hline \multirow{2}{*}{$\begin{array}{c}\text { Beachrocks } \\
\text { (Pierre de } \\
\text { Sete) }\end{array}$} & $\begin{array}{l}\text { Sample } 1 \text { (upper } \\
\text { part of the "Pierre } \\
\text { de Sète") }\end{array}$ & $\begin{array}{l}\text { Cemented } \\
\text { littoral sand }\end{array}$ & $\begin{array}{l}\text { Poz- } \\
42577\end{array}$ & $110 \pm 80$ & $17,896 \pm 114$ \\
\hline & $\begin{array}{c}\text { Sample } 2 \text { (lower } \\
\text { part of the" Pierre } \\
\text { de Sète") }\end{array}$ & $\begin{array}{l}\text { Cemented } \\
\text { littoral sand }\end{array}$ & $\begin{array}{l}\text { Poz- } \\
42578\end{array}$ & $0,050 \pm 90$ & $18,882 \pm 92$ \\
\hline
\end{tabular}

